\title{
Para onde ir? A trajetória eleitoral dos prefeitos das capitais estaduais brasileiras (1996-2014)
}

Alvaro Augusto de Borba Barreto

\section{Introdução ${ }^{1}$}

A carreira política é de alto risco, pois nenhuma conquista se mostra sólida e permanente. Os "políticos profissionais" estão sempre submetidos à possibilidade de perderem o "emprego", visto que os mandatos são renovados periodicamente. Para permanecer no "mercado", precisam passar pelo crivo do voto e, antes disso, ser indicados pelo partido. Em caso de derrota, devem procurar novos "postos de trabalho", como um cargo de nomeação e/ou esperar no mínimo dois anos por nova oportunidade nas urnas. Enfim, a construção da carreira é uma tarefa desafiadora, em que percalços e dissabores estão permanentemente no horizonte, razões pelas quais a decisão sobre o passo seguinte torna-se estratégica para minimizar ou eliminar eventuais fracassos, viabilizar sucessos, e, assim, garantir a manutenção na atividade.

$\mathrm{O}$ artigo procura se somar à literatura que investiga essas questões no Brasil. No entanto, ao contrário da maioria dos estudos que está voltada aos membros do Legislativo (deputados federais, em especial), este tem como objeto a decisão relativa à continuidade da carreira tomada por titulares do Executivo, no caso os prefeitos das capitais estaduais eleitos entre 1996 e 2008. Busca identificar se procuraram novos postos eletivos, em caso positivo, quais foram eles e os resultados alcançados, com vistas a verificar a presença de alguma tendência predominante.

Esse é um debate ao qual a ciência política vem se dedicando há algumas décadas. No caso do Brasil, um conjunto significativo de estudos atenta à circulação e ao recrutamento parlamentar, e procura calcular as taxas de desistência e reapresentação, de reeleição, renovação e retenção na Câmara dos Deputados, em uma série histórica ampla, que abrange de 1946 a 2010, ou diferentes recortes nesse intervalo, a depender do período em que a pesquisa foi realizada (W. G. Santos, 1971, 1987, 1997, 2002, 2003; Fleischer, 1980, 1981; Soares e D'araujo, 1993; Mainwaring, 1991; Figueiredo e Limongi, 1996, 2002; Schmitt, 1999; F. Santos, 2000, 2002, 2010; Marenco dos Santos, 2000; Pereira e Rennó, 2001, 2007; Nicolau, 2002; Araújo, 2002; Leoni, Pereira e Rennó, 2003; Samuels, 2003; Pegurier, 2009; Oliveira, 2009; Mancuso et al., 2013). Também figuram análises comparadas entre esses indicadores e aqueles registrados em

${ }^{1}$ A coleta de dados contou com a colaboração inestimável de Elenice da Silva Cardozo. 
outros países latino-americanos (Marenco dos Santos, 2004; Botero e Rennó, 2007; Santana, 2008).

Mais do que simples registro do comportamento da "classe política", essas taxas têm servido para a discussão de questões relativas aos membros do Legislativo e ao próprio parlamento, ambas desenvolvidas a partir de modelos explicativos formulados para a análise do Congresso norte-americano: a teoria da institucionalização de Polsby (1968) e a da ambição de Schlesinger (1966).

Os resultados indicaram que o parlamento do país seria pouco institucionalizado, pois não geraria os incentivos necessários para a construção da carreira política eminentemente parlamentar e teria baixa capacidade de reter seus membros; inexistiriam mecanismos internos de "promoção" e haveria pouco estímulo ao investimento na especialização por meio de comissões (Figueiredo e Limongi, 1996; F. Santos, 2000).

Na mesma medida, Samuels (2003) registrou a prevalência da "ambição progressiva"2 - a disposição dos deputados de buscar um posto mais alto na hierarquia, com interesse em cargos executivos de qualquer âmbito. O que essa teoria chama de ambição não é propriamente a vontade dos políticos - pois, em condições ideais, eles sempre vão procurar o cargo mais elevado -, e sim um cálculo de oportunidade em que a decisão depende da estrutura de oportunidades oferecida pelo sistema político e da avaliação dos custos e dos dividendos envolvidos na escolha (Schlesinger, 1966; Black, 1972; Rohde, 1979). Por consequência, a intenção de "progredir" também revelaria a pouca importância atribuída ao cargo que detinham, a vulnerabilidade daqueles que pretendiam continuar no parlamento ("ambição estática"), bem como explicaria os baixos índices de sucesso alcançado, pois seriam vencidos por candidatos com pouca ou nenhuma experiência anterior no parlamento e/ou sem qualquer experiência política, os chamados outsiders (Marenco dos Santos, 2000). Assim, reafirmava-se o juízo contido nos estudos calcados na teoria da institucionalização.

Investigações mais recentes matizaram essas interpretações e reforçaram que estavam equivocadas, especialmente porque não atentavam às distinções entre os sistemas políticos brasileiro e norte-americano. A base do argumento é que as estruturas de oportunidades não são idênticas, o que produz escolhas distintas de carreira, mas igualmente racionais. Não é possível afirmar que os deputados com "ambição estática" sejam os mais frágeis eleitoralmente, pois, diante dos riscos associados à busca pelos cargos mais elevados, a reeleição também é cultivada por políticos relevantes (Leoni, Pereira e Rennó, 2003). Na mesma medida, como o cargo é preenchido pelo sistema proporcional com "lista aberta" - e não pelo sistema majoritário, como ocorre nos EUA -,

\footnotetext{
2 Samuels (2003) a chama de "ambição extralegislativa"; Bourdoukan (2006), de "executiva"; Mancuso et al. (2013), de "opção executiva". Todas se referem ao mesmo fenômeno.

${ }^{3}$ Como não há regra da senioridade a prestigiar a permanência na Câmara brasileira, pode-se dizer que aqui reeleger-se é "ambição formalmente estática", ao contrário do que ocorre nos EUA, onde permanecer implica galgar postos no interior do Legislativo.
} 
PARA ONDE IR? A TRAJETÓRIA ELEITORAL DOS PREFEITOS DAS CAPITAIS ESTADUAIS BRASILEIRAS (1996-2014)

os votos obtidos pessoalmente são essenciais para que o candidato fique bem posicionado na lista, o que torna a disputa mais incerta e não fornece vantagens claras ao incumbent.

Nesse diapasão, destaca-se a ponderação de Figueiredo e Limongi (1996, p. 26), segundo a qual "não se pode falar propriamente de uma carreira parlamentar" no país. O que poderia soar como a constatação de um cenário indesejável, pois distanciado daquele existente nos EUA, é amenizado quando os autores complementam que, nem por isso, é possível falar em "amadores" ou "diletantes", visto que "a carreira parlamentar é parte da carreira política, um ponto de passagem para postos mais atrativos, no Executivo". Em acréscimo, lembram que "sair do parlamento para a ele retornar pode ser, por paradoxal que pareça, a melhor estratégia do ponto de vista eleitoral" (1996, p. 28), o que geraria o chamado efeito zigue-zague (F. Santos, 2000). Para dar conta dessa peculiaridade, Santana (2008) propôs uma nova modalidade de ambição, a "dinâmica", a permanência na atividade por meio da busca de cargos executivos e legislativos.

Outra linha passou a negar que as taxas de reapresentação e de reeleição fossem tão baixas e, consequentemente, que não haveria razão para avaliações tão negativas. 0 argumento era de que os índices registrados no Brasil são elevados por si sós ou cresciam conforme a recorrência de eleições em períodos de normalidade institucional, tendo sido interpretados como insuficientes porque o parâmetro adotado era aquele registrado nos EUA, o qual não constituía regra em relação aos parlamentos do mundo, e sim exceção (Leoni, Pereira e Rennó, 2003; Santana, 2008; Oliveira, 2009; Pegurier, 2009; F. Santos, 2010; Mancuso et al., 2013; Graça e Souza, 2014).

Mais recentemente, um conjunto de estudos analisou os deputados que concorrem a prefeito (Bourdoukan, 2006; Matos, 2010; Pinto, 2012; Graça e Souza, 2014). Os resultados revisaram a máxima dos incentivos produzidos pelos cargos executivos, pois uma parcela deles concorre não simplesmente porque deseja se eleger, e sim porque há menos riscos associados e mais dividendos presumíveis na empreitada. O risco é amortizado porque deputados não precisam abrir mão do mandato para concorrer. No campo dos dividendos - além da possibilidade de ser eleito, é claro -, o fato de terem participado da disputa majoritária reforça a imagem para a tentativa de reeleição legislativa e reduz as incertezas que acompanham o sistema proporcional do país.

Como evidencia Oliveira (2009), índices expressivos de não apresentação e de insucesso são compatíveis com índices elevados de ingresso de novatos (membros do Executivo, "calouros" ou aqueles vindos dos Legislativos subnacionais e que ascenderam na carreira) e, igualmente, com alta quantidade de retornos de ex-parlamentares (que encerraram o período em cargos executivos), sem que isso implique baixa institucionalização ou permita concluir a inexistência de políticos profissionais. Ao contrário, pode ser indício de institucionalização e valorização do parlamento como parte da carreira política. 
Nesse cenário ganha projeção o modelo formulado por Borchert (2009, 2011), autor que segue o modelo de Schlesinger, calcado na estrutura de oportunidades (disponibilidade, acessibilidade, atratividade). Ele constata que o Brasil possui ampla oferta (motivada pela quantidade e diversidade de oportunidades oferecidas pelo calendário eleitoral), que os cargos apresentam níveis de atração, representação e recursos políticos diversos, bem como que inexistem fronteiras definidas entre as instâncias da federação. Tais elementos fazem com que não haja uma hierarquia claramente definida dos postos políticos, e sim a possibilidade de trilhar diversos caminhos nessa estrutura. Não se pode compreender a construção das carreiras e as escolhas promovidas pelos políticos por meio da aplicação direta dos critérios propostos pelo autor norte-americano, pois "subir", "descer", "ambição estática", "progressiva" ou mesmo "regressiva" ${ }^{4}$ explicam pouco as rotas seguidas.

Borchert (2011) classifica a carreira no país como "integrada", aquela em que há alta maleabilidade e muitas formas de ingresso, de mudanças de posição e na qual se alternam postos de nível federal, estadual e municipal, assim como de âmbito executivo e legislativo, os quais são buscados sempre com vistas à permanência na atividade pelo período mais longo possível ${ }^{5}$.

Como foi indicado no princípio do texto, este artigo procura se somar a essa literatura, mas o faz a partir dos que ocupam um posto eletivo no Executivo. No caso específico, os prefeitos das 26 capitais estaduais do país. Esse cargo pode ser mais valioso do que aqueles existentes na Câmara dos Deputados, como indicam os estudos, mas traz o inconveniente de ser transitório, dado que não é possível nele permanecer indefinidamente, ainda que o político tenha elevados índices de aprovação e apresente ampla possibilidade de, se fosse permitido, ser eleito para mais do que dois mandatos consecutivos.

Diante dessa circunstância, pode-se considerar que a decisão sobre o próximo passo daqueles que exercem mandato no Executivo é mais dramática do que a dos que estão no Legislativo. Estes têm um leque de possibilidades que contempla as diferentes "ambições": permanecer no posto já ocupado - o que em teoria pode ocorrer indefinidamente -; ascender ou regredir no âmbito legislativo; pleitear cargo executivo; ou, simplesmente, não disputar pleito algum. Aqueles com mandato executivo inevitavelmente precisam buscar outro cargo caso desejem dar continuidade à carreira. Os chefes do Executivo também se defrontam com outro dilema que não é compartilhado pelos parlamentares: o de ter de renunciar ao pretenderem outro cargo ou de ficar algum tempo sem mandato, caso o cumpram integralmente. Ainda que tais peculiaridades

\footnotetext{
4 Expressão proposta por Leoni, Pereira e Rennó (2003) para contemplar os deputados federais que buscam ser deputado estadual. Mancuso et al. (2013) preferem a expressão "opção subnacional".

5 "Integrada" é um dos padrões da carreira propostos pelo autor. Os outros dois são: "unidirecional", quando o político passa de um nível a outro, sem retorno ao anterior; e "alternativo", quando ele prefere se manter em um determinado nível, sem motivação para mudar. Eles são muito próximos às ambições "progressiva" e "estática" de Schlesinger (1966), logo a principal inovação em relação ao autor norteamericano está na proposição da carreira "integrada".
} 
sejam de amplo conhecimento - como se verifica pela ideia do efeito zigue-zague -, a ciência política não tem problematizado a decisão dos chefes do Executivo, o que decorre do fato de as investigações estarem focadas em postos legislativos ou por considerarem que a limitação no tempo de permanência no cargo torna imperativo que tal escolha seja feita e, assim, ela se torna menos dramática e complexa em termos de carreira do que a que envolve os membros do parlamento.

O pressuposto deste artigo é diverso. Ele investe na perspectiva de que, pelo limite de permanência no Executivo e diante do interesse de manter a carreira, o político se defronta com uma série de possibilidades e de circunstâncias. A literatura aponta para a grande possibilidade de que, em algum momento dessa trajetória futura, esse político vá (ou retorne) ao Legislativo, porém cabe perguntar: tal cargo é pretendido imediatamente? Ou trajetórias distintas se apresentam, como sugere a perspectiva proposta por Borchert? E quais são elas? Igualmente, qual o timing dessa busca por um novo cargo: no 10 mandato, durante o $2^{\circ}$, após encerrar os dois mandatos? $\mathrm{E}$ quais os resultados alcançados? Eles variam conforme o cargo pretendido? A expectativa do resultado modela a decisão sobre o passo a ser dado?

Para essas questões a ciência política não tem respostas efetivas e empiricamente embasadas. Essa investigação pretende coletar informações e produzir análises que permitam responder a alguns desses desafios. Obviamente, os resultados alcançados não podem ser generalizados para toda a classe política ou todos os cargos, em razão de uma série de limitações e de especificidades do objeto escolhido, que serão apontadas na sequência. Porém, eles certamente possibilitam dar explicações mais efetivas em relação ao tema.

\section{Desenho da investigação}

O artigo tem com objeto os prefeitos das 26 capitais estaduais brasileiras no período 1996-2008, o que compreende quatro disputas e 104 mandatos. Por conta de reeleição imediata, de renúncias e de consequentes substituições, 77 indivíduos ocuparam o cargo e o exerceram em 118 períodos correspondentes a mandatos completos ou incompletos, os quais constituem o universo pesquisado.

A eleição de 1996 é o ponto de partida, tendo em vista que esses prefeitos foram os primeiros a ter a possibilidade de buscar a reeleição imediata ${ }^{6}$. E o recorte temporal se encerra em 2008 porque o mandato finalizou em 2012 e a necessidade de decidir o passo seguinte na trajetória já se impôs de modo definitivo. Pela mesma razão, e em condições normais, aqueles que atingiram o cargo na eleição de 2012 ainda estavam no exercício por ocasião da redação do artigo e não se defrontaram com as mesmas decisões relativas à continuidade da carreira.

\footnotetext{
${ }^{6}$ A Emenda Constitucional que permite a reeleição imediata aos chefes do Executivo dos três níveis da federação foi promulgada em junho de 1997.
} 
O artigo sistematiza dados a respeito dos mandatos eletivos a que concorreram após tomarem posse e/ou imediatamente depois de deixarem a prefeitura, o que abarca um período máximo de dez anos. No conjunto, acompanha nove disputas: quatro de âmbito municipal (2000, 2004, 2008 e 2012) e cinco de amplitude estadual-nacional (1998, 2002, 2006, 2010 e 2014), com informações coletadas no site do Tribunal Superior Eleitoral (TSE).

A classificação das motivações a partir das quais foi decidido não concorrer exigiu outro procedimento metodológico. Foram consultados livros, artigos e outros trabalhos acadêmicos, bem como sites de órgãos de imprensa e demais fontes disponíveis via internet, em busca das informações que permitissem identificar as circunstâncias de cada caso e, ao mesmo tempo, reuni-las por afinidade em categorias suficientemente sintéticas. Tais categorias serão apresentadas e explicadas na continuidade do texto.

\section{Quadro 1}

Prefeito das capitais estaduais que renunciou ao cargo (Brasil, 1996-2012)

\begin{tabular}{|c|c|c|c|c|c|}
\hline \multirow[b]{2}{*}{ Município } & \multicolumn{3}{|c|}{ Renúncia } & \multicolumn{2}{|l|}{ Substituto } \\
\hline & Ano & Prefeito & $\begin{array}{l}\text { Motivação/ } \\
\text { Concorrer a }\end{array}$ & Nome & Concorreu \\
\hline Porto Velho & 1998 & Chiquilito Erse & Saúde & Carlos Alberto Camurça & Venceu \\
\hline Belo Horizonte & 2002 & Célio de Castro & Saúde & Fernando Pimentel & Venceu \\
\hline Natal & 2002 & Wilma Faria & Governador & $\begin{array}{c}\text { Carlos Eduardo Nunes } \\
\text { Alves }\end{array}$ & Venceu \\
\hline Porto Alegre & 2002 & Tarso Genro & Governador & João Verle & Não \\
\hline Rio Branco & 2002 & Flaviano & Governador & Isnard Barbosa Leite & Não \\
\hline São Luís & 2002 & Jackson Lago & Governador & Carlos Tadeu Palacio & Venceu \\
\hline Manaus & 2004 & $\begin{array}{c}\text { Alfredo } \\
\text { Nascimento }\end{array}$ & Ser ministro & Luiz Alberto Carijó & Não \\
\hline Aracaju & 2006 & Marcelo Déda & Governador & Edvaldo Nogueira & Venceu \\
\hline Boa Vista & 2006 & Teresa Surita & Senador & $\begin{array}{c}\text { Iradilson Sampaio de } \\
\text { Souza }\end{array}$ & Venceu \\
\hline São Paulo & 2006 & José Serra & Governador & Gilberto Kassab & Venceu \\
\hline Cuiabá & 2010 & $\begin{array}{c}\text { Wilson Pereira } \\
\text { dos Santos }\end{array}$ & Governador & Francisco Gallindo & Não \\
\hline Curitiba & 2010 & Beto Richa & Governador & Luciano Ducci & Perdeu \\
\hline Goiânia & 2010 & Iris Rezende & Governador & Paulo de Siqueira Garcia & Venceu \\
\hline João Pessoa & 2010 & Ricardo Coutinho & Governador & Luciano Agra & Não \\
\hline Porto Alegre & 2010 & José Fogaça & Governador & José Fortunati & Venceu \\
\hline Teresina & 2010 & Silvio Oliveira & Governador & Elmano Férrer & Perdeu \\
\hline
\end{tabular}

Fonte: Elaboração própria com base em dados do TSE. 
No período analisado, 70 indivíduos foram eleitos prefeitos e outros sete chegaram ao cargo exclusivamente ao substituir em definitivo o titular. É preciso fazer referência às substituições, pois, como mostra o Quadro 1, elas não são incomuns: houve 16, todas motivadas por renúncia (duas por doença; uma para assumir posto de nomeação política e 13 com vistas a concorrer a outro cargo). Em 15 casos foi efetivado o vice-prefeito e em um, o presidente da Câmara de Vereadores. Dos substitutos: nove concorreram e foram mantidos no cargo (reeleitos, conforme o entendimento legal ${ }^{7}$ ), dois foram rejeitados nas urnas e cinco sequer se candidataram.

No levantamento da continuidade da carreira dos prefeitos foi contabilizado como cargo obtido somente aquele alcançado diretamente. Não valeu como tal se houve disputa para o Legislativo e candidato ficou como suplente, ainda que depois tenha sido efetivado em caráter temporário ou definitivo, ou se perdeu a disputa a um posto executivo, apesar de ter sido guindado ao cargo em razão da cassação daquele originalmente eleito. Contudo, essas informações foram registradas e, quando consideradas relevantes, inseridas na análise.

Cabe explicar, ainda, que não foram incluídos os cargos de nomeação - ministro, secretário etc. -, embora eles compreendam parcela significativa do elenco de oportunidades à disposição dos políticos e sejam por eles cobiçados, especialmente quando sofrem uma derrota nas urnas, ficam sem mandato ou decidem abandonar/interromper a carreira eleitoral. A exclusão deriva do interesse em enfocar os postos eletivos. Contudo, esses dados foram coletados e utilizados se importantes para explicar a trajetória dos atores.

A escolha dos prefeitos das capitais estaduais é motivada por duas razões. A primeira, o fato de eles apresentarem uma série de características comuns: venceram um processo eleitoral realizado conforme as mesmas regras ${ }^{8}$, para exercerem mandatos de idêntica duração, bem como ocupam a mesma posição institucional e possuem poderes equivalentes - ainda que existam significativas diferenças entre os municípios governados e entre os recursos associados a tais localidades ${ }^{9}$. Porém, não seria motivação suficiente, pois todos os prefeitos possuem um elenco comum de prerrogativas - e eles são mais de 5 mil. É preciso acrescentar a segunda razão: eles compartilham o governo de municípios que, por serem as capitais de seus respectivos estados, possuem importância política regional, correspondem às localidades mais

\footnotetext{
7 A interpretação da Justiça Eleitoral é de que quem substitui permanentemente o titular está em 10 mandato e, por isso, se concorrer ao cargo, pleiteia o $2^{\circ}$ e último mandato consecutivo.

${ }^{8} \mathrm{~A}$ diferença reside no requisito a cumprir para vencer o pleito, pois alguns concorreram em municípios com menos de 200 mil eleitores, nos quais a eleição se decide por maioria simples, o que ocorreu cinco vezes em 2000; quatro em 2004; três em 2008; e duas em 2012, quais sejam: Porto Velho (2000); Macapá (2000, 2004); Rio Branco (2000, 2004, 2008); Boa Vista e Palmas, em que houve turno único ao longo de todo o período.

${ }^{9}$ Um exemplo: São Paulo lidera o ranking populacional entre as capitais, com 11,2 milhões de habitantes, enquanto Palmas, a última nesse quesito, atingiu 228 mil habitantes, contingente que a excluía dentre os 100 mais populosos municípios do país, conforme dados do Censo 2010 (IBGE).
} 
populosas ${ }^{10}$, compõem o centro de áreas metropolitanas ${ }^{11}$, apresentam grande influência econômica, além de concentrarem o poder administrativo e político do próprio estado.

Figura 1

Estrutura de carreira política no Brasil

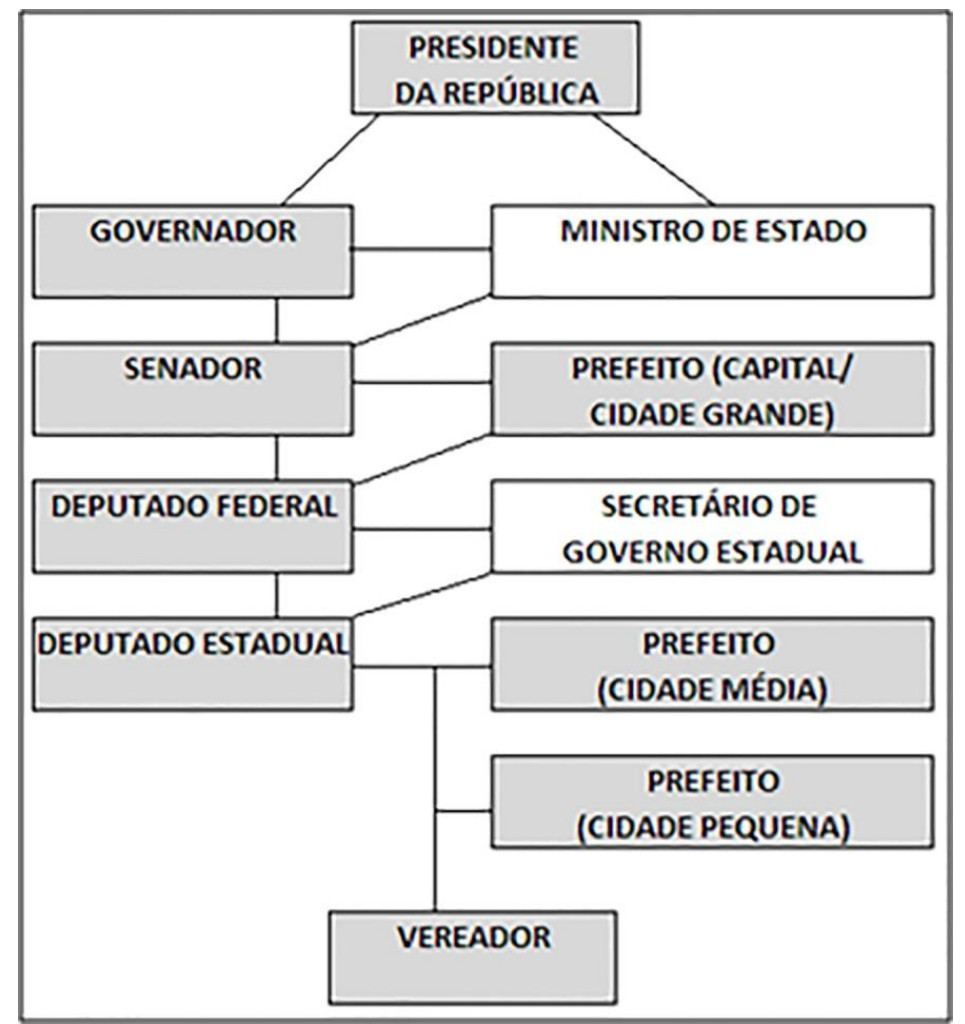

Fonte: Miguel, 2003.

Observação: As caixas em cinza representam cargos eleitos por votação popular.

Cabe ponderar o posicionamento do cargo de prefeito de capital na hierarquia política do país. A basear-se no modelo sugerido por Miguel (2003) ${ }^{12}$, reproduzido na Figura 1, ele tem acima: presidente, ministros e governadores; ao lado, senadores; abaixo, deputados federais e estaduais, mais vereadores e a grande maioria dos

\footnotetext{
${ }^{10}$ As exceções são Florianópolis (SC) e Vitória (ES), superadas, respectivamente, por Joinville e Vila Velha (sendo que esta pertence à região metropolitana de Vitória) (IBGE).

${ }^{11}$ Das 26 capitais estaduais, 20 compreendem uma região metropolitana (Freitas, 2010).

12 O autor não aponta os critérios a partir dos quais o construiu, apresentando-o como um modelo "intuitivo", mas é evidente que o nível da federação, o poder a que eles se referem, a quantidade de vagas e de governados são elementos que contribuem para a distribuição dos cargos no diagrama. Contudo, o modelo de Miguel não inclui os vices, os suplentes de senador e a ampla maioria dos cargos de nomeação dos três níveis da federação. O autor cita os vices, mas preferiu deixá-los de fora, o que abre a discussão sobre a relevância deles, como o fazem Maluf (2006) e Santana (2008). Este artigo preferiu inserir cada vice abaixo do respectivo titular, mas acima dos cargos em posição inferior ao do titular. Por exemplo, o vice-governador está acima do prefeito das capitais.
} 
PARA ONDE IR? A TRAJETÓRIA ELEITORAL DOS PREFEITOS DAS CAPITAIS ESTADUAIS BRASILEIRAS (1996-2014)

prefeitos, o que permite supor que há várias alternativas de caminhos para a continuidade na atividade, uma das peculiaridades da estrutura de carreira no Brasil, como argumenta Borchert $(2009,2011)$. Por estarem em um posto de relevância política, colocado quase a "meio caminho" entre o piso (vereador) e o topo (presidente), todos os cargos são, de um modo ou de outro, viáveis e razoáveis.

Em razão desse conjunto de ponderações, supõe-se que esses prefeitos tenham possibilidade de dar continuidade à carreira eleitoral e busquem novos mandatos. Essa é a hipótese 1 (H1) do artigo. Todavia, é preciso especular sobre quais caminhos eles escolhem e o timing da decisão, ou seja, quando procuram esses mandatos.

Antes de formular essas hipóteses e de testá-las, é relevante evidenciar algumas características institucionais - o que Schlesinger (1966) chama de "estrutura de oportunidades" -, pois elas condicionam as escolhas a serem realizadas pelos prefeitos.

O cargo de chefe do Executivo (prefeito, governador e presidente) apresenta duas peculiaridades relevantes para os cálculos relativos à decisão sobre o próximo passo da carreira: (1) a limitação no número de mandatos sucessivos que podem ser exercidos (dois, desde o advento da reeleição) e, consequentemente, no tempo em que nele é possível permanecer (oito anos, no máximo); (2) a obrigatoriedade de renunciar para concorrer a um dos postos em disputa, com exceção de candidatura à reeleição. Portanto, o chefe do Executivo sabe que o cargo possui um horizonte temporal delimitado, o que, em tese, estimula-o a buscar outro imediatamente ou, ao menos, torna claro que, se não o fizer, ficará sem mandato. A renúncia impõe custos que precisam ser bem dimensionados, pois implica perder algo já obtido com vistas a alcançar novo ganho, sendo que a derrota o deixará sem "nada".

Dois elementos importantes nessa equação e na decisão a ser tomada são o tempo que ainda resta de mandato e se é possível pleitear a reeleição. Um chefe do Executivo que está em $1^{\circ}$ mandato: (a) se quiser um novo cargo precisa renunciar até seis meses antes da eleição que ocorre em outubro do $2^{\circ}$ ano; ou (b) pode cumpri-lo integralmente e, se desejar, concorrer para um novo período no mesmo cargo. Ao optar pela tentativa de reeleição e sendo bem-sucedido, surgem duas novas possibilidades: (c) se quiser concorrer a outro cargo, deve renunciar até seis meses antes da realização da próxima eleição, o que ocorre em outubro do $2^{\circ}$ ano (igual à situação "a"); ou (d) pode cumpri-lo integralmente, o que implica ficar em seguida sem mandato e esperar, no mínimo, dois anos para tentar outro posto nas urnas.

Há outras duas possibilidades não referidas no parágrafo anterior, propiciadas pelo calendário brasileiro que prevê eleições a cada dois anos - e é nelas que residem as diferenças no elenco de oportunidades disponíveis a prefeito, de um lado, a governador e presidente, de outro. Não cumprida a renúncia imposta pela situação "a", não se afirma inevitavelmente " $b$ ", e o mesmo se repete no caso da opção "c" em relação a " $d$ ". Isso porque, tendo chegado o último ano do mandato ( $1^{\circ}$ ou $\left.2^{\circ}\right)$, ocorre nova eleição, e é possível ao chefe do Executivo renunciar até seis meses antes do evento e concorrer a outro cargo. 
Nessa situação, o prefeito encontra à disposição os postos de vice-prefeito e de vereador $^{13}$. E, diante dessas alternativas típicas da "ambição regressiva", é provável que, ao término do 10 mandato, busque a reeleição (ou não concorra) e, ao final do 20 , não dispute o pleito. Igualmente, se não renunciar em meio ao $2^{\circ}$ período para buscar outro cargo, ele automaticamente optou por cumprir o mandato. Assim, para o prefeito, a não ocorrência de "a" muito seguramente implica a ocorrência de "b", o que se repete com "c" em relação a "d".

O cenário não é o mesmo para presidente e governador. Ao chegar ao ano derradeiro do 10 mandato, o provável é que o governador concorra à reeleição ou não se apresente. Se ambicionar outro cargo eletivo e renunciar seis meses antes do pleito, ele encontra à disposição uma oferta diversificada: senador, deputado federal e estadual, mais presidente e vice. Cargos como senador ou vice-presidente podem ser um refúgio dourado e/ou promoção na carreira, quando, por algum motivo, ele não puder ou não quiser concorrer à reeleição ${ }^{14}$. Quando está em $2^{\circ}$ mandato, as possibilidades de pleitear outro cargo se tornam mais relevantes, visto não ter como prosseguir naquele já ocupado.

Para o presidente valem as mesmas possibilidades. Contudo, por ser o topo da carreira, é ainda mais provável que, se estiver em 10 mandato, decida pela reeleição ou por não concorrer, pois nenhum outro posto deve lhe interessar de imediato. Se estiver em $2^{\circ}$ mandato, vai cumprir o mandato, pois não deve abrir mão de aproximadamente nove meses no cargo eletivo mais alto da República para tentar ocupar qualquer outro posto.

Pode-se ir mais longe e lembrar que, pelas mesmas razões, também as situações narradas nas alternativas "a" e "c", relativas à renúncia na metade do 10 ou do 20 mandato para concorrer a outro cargo, não são idênticas para todos os chefes do Executivo. Isso porque parece pouco provável que o presidente ou um governador renuncie ao cargo para concorrer a prefeito ( $\mathrm{e}$, ainda menos provável, a vice-prefeito ou a vereador). Mas é mais razoável imaginar que um prefeito possa renunciar com vistas a conquistar um cargo estadual ou nacional - e esses impulsos são mais fortes no $2^{\circ}$ do que no $1^{0}$ mandato, tendo em vista a impossibilidade de uma nova reeleição. Ou seja, caso busque imediatamente outro cargo, um governador pode esperar a eleição que ocorrerá concomitantemente ao término do mandato (e ainda mais provavelmente se ele estiver no $2^{\circ}$ ), momento em que o elenco de oferta é mais vantajoso em relação ao cargo que ele já atingiu. O prefeito, se pretender de pronto outro posto eletivo (o que é igualmente mais provável de ocorrer se ele estiver no 20 mandato), é levado a renunciar

\footnotetext{
${ }^{13}$ A opção ao término do $2^{\circ}$ mandato é apenas de concorrer a vereador, já que a legislação o impede de disputar o cargo de vice-prefeito (Brasil, TSE, 2015). Até 2008 havia a alternativa de transferir o título para outro município e, nele, concorrer novamente a prefeito, pois a interpretação era de que a lei vedava um terceiro mandato sequencial apenas no mesmo município. Desde então, não existe mais tal possibilidade, informalmente denominada de "prefeitos itinerantes" (Valor Econômico, 1 ago. 2012).

14 Eles podem concorrer ao cargo de deputado, mas seria "ambição regressiva", e, por isso, pouco provável.
} 
a dois anos de mandato e a concorrer nas eleições nacional-estaduais, pois, se não o fizer, precisará esperar dois anos após o término do seu governo para ter nova oportunidade de se tornar deputado, senador, governador ou presidente (e seus respectivos vices).

Diante dessas peculiaridades, é preciso desdobrar a H1. Propõe-se que: quando em 10 mandato, os prefeitos analisados não renunciam para concorrer a outro posto, e sim preferem tentar a reeleição $(\mathrm{H} 2)$; se forem bem-sucedidos, abrem mão do cargo na metade do $2^{\circ}$ período para pleitear algum posto mais alto da hierarquia, concebida nos moldes propostos por Miguel (2003), ou seja, concorrer a senador, governador, vicegovernador ou presidente (H3). Espera-se, ainda, que, em razão da relevância do cargo de prefeito de capital, a grande maioria conquiste o próximo mandato pretendido $(\mathrm{H} 4)$.

Os dados a serem analisados estão escalonados por mandato ( $1^{\circ}$ ou $2^{\circ}$ ) e, quando for o caso, por ano ( $2^{\circ}$ ou $\left.4^{\circ}\right)$. Antes, é preciso lembrar que as incidências a serem apresentadas se referem aos prefeitos que, na ocasião dos pleitos, exerciam o cargo, desse modo as somas não abrangem o conjunto dos 77 indivíduos estudados ou os 118 mandatos que eles exerceram. Conforme a situação - a ser ponderada por ocasião da apresentação dos dados - tal universo se contrai ${ }^{15}$.

\section{As decisões tomadas enquanto exerciam o cargo}

A Tabela 1 se refere à decisão tomada pelos prefeitos frente à eleição realizada dois anos após a disputa municipal, primeira oportunidade para obter outro posto e, portanto, a escolha inicial relativa à continuidade da carreira. Igualmente, abarca a próxima disputa local, realizada no $4^{\circ}$ ano do mandato.

Tabela 1

Decisão tomada durante o mandato pelos prefeitos das capitais estaduais (Brasil, 1996-2014)*

\begin{tabular}{|l|c|c|c|c|c|c|}
\hline Concorrer & \multicolumn{3}{|c|}{$\mathbf{2}^{\mathbf{0}}$ ano } & \multicolumn{3}{c|}{$\mathbf{4}^{\mathbf{0}}$ ano } \\
\hline & $\mathbf{1 0}^{\mathbf{0}}$ mandato & $\mathbf{2}^{\mathbf{0}}$ mandato & Total & $\mathbf{1 0}^{\mathbf{0}}$ mandato & $\mathbf{2}^{\mathbf{0}}$ mandato & Total \\
\hline \multirow{2}{*}{ Sim } & 4,8 & 21,7 & 12,0 & 80,8 & & 56,7 \\
& $(3)$ & $(10)$ & $(13)$ & $(59)$ & & $(59)$ \\
\hline \multirow{2}{*}{ Não } & 95,2 & 78,3 & 88,0 & 19,2 & 100 & 43,3 \\
& $(59)$ & $(36)$ & $(95)$ & $(14)$ & $(31)$ & $(45)$ \\
\hline \multirow{2}{*}{ Total } & $\mathbf{1 0 0}$ & $\mathbf{1 0 0}$ & $\mathbf{1 0 0}$ & $\mathbf{1 0 0}$ & $\mathbf{1 0 0}$ & $\mathbf{1 0 0}$ \\
& $\mathbf{( 6 2 )}$ & $\mathbf{( 4 6 )}$ & $\mathbf{( 1 0 8 )}$ & $\mathbf{( 7 3 )}$ & $\mathbf{( 3 1 )}$ & $\mathbf{( 1 0 4 )}$ \\
\hline
\end{tabular}

Fonte: TSE.

* Os valores estão expressos em percentual. Os números absolutos figuram entre parênteses.

\footnotetext{
15 Do total não se obtém automaticamente o contingente dos que tomaram uma decisão, pois três renunciaram ao longo do $1^{\circ}$ ou do $2^{\circ}$ período, 16 se tornaram prefeito em algum momento do mandato e quatro foram reeleitos em 2012 e ainda não tinham atingido o $4^{\circ}$ ano por ocasião da redação do artigo.
} 
Os dados confirmam a $\mathrm{H} 2$ : quando estão no 20 ano do $1^{\circ}$ período, a quase totalidade dos prefeitos optou por não concorrer: 4,8\% abriram mão do mandato e $95,2 \%$ não buscaram outro cargo, pois valorizam mais a oportunidade de concorrer à reeleição, o que evidencia a importância, nessa circunstância, de ser prefeito. E tal se comprova quando a nova eleição municipal surge (40 ano), pois $80,8 \%$ concorreram.

A situação é diferente quando os prefeitos estão no 20 mandato. A impossibilidade de prosseguir no cargo se mostra no horizonte e há uma espécie de amortização do valor de ser prefeito, de modo que um contingente mais expressivo optou por abrir mão dos dois anos derradeiros de mandato e tentou alcançar outro cargo. Os $21,7 \%$ registrados correspondem a quatro vezes mais do que aqueles em 10 período $(4,8 \%)$ que tomaram a mesma decisão, de modo que $76,9 \%$ das escolhas de concorrer em meio ao mandato aconteceram no $2^{\circ}$ período (10 em 13). Como esperado, os reeleitos que não renunciaram não se apresentaram ao término desse mandato derradeiro, pois não tinham interesse de se tornar vereador, o único cargo então disponível. Na realidade, para estes a escolha havia sido feita dois anos antes.

Tabela 2

Prefeitos das capitais estaduais que, por vontade própria, completaram o mandato (Brasil, 1996-2012)*

\begin{tabular}{|l|c|c|c|}
\hline Completou & $\mathbf{1}$ ' mandato & $\mathbf{2}^{\mathbf{0}}$ mandato & Total \\
\hline \multirow{2}{*}{ Não } & 3,9 & 26,2 & 11,9 \\
& $(3)$ & $(11)$ & $(14)$ \\
\hline \multirow{2}{*}{$\mathrm{Sim}$} & 96,1 & 73,8 & 88,1 \\
& $(73)$ & $(31)$ & $(104)$ \\
\hline \multirow{2}{*}{ Total } & $\mathbf{1 0 0}$ & $\mathbf{1 0 0}$ & $\mathbf{1 0 0}$ \\
& $\mathbf{( 7 6 )}$ & $\mathbf{( 4 2 )}$ & $\mathbf{( 1 1 8 )}$ \\
\hline
\end{tabular}

Fonte: TSE.

* Os valores estão expressos em percentual. Os números absolutos figuram entre parênteses.

A Tabela 2 traz os prefeitos que completaram o mandato, com a intenção de identificar aqueles que deixaram o cargo para concorrer. Ela inclui os que assumiram o cargo pela renúncia do titular, mas não considera os dois casos em que houve renúncia por questões de saúde (um em cada mandato) e os quatro cujos mandatos estavam em andamento, pois não o completaram por questões distintas à análise e a inclusão deles afetaria os resultados.

Ela permite verificar que a H3 não se confirma em sua versão original, pois a preferência majoritária dos prefeitos não foi pular imediatamente para outro cargo. Parcela amplamente majoritária $(88,1 \%)$ completou o mandato obtido: quando estavam no $1^{\circ}$ governo, pode-se considerar que a expectativa de um $2^{\circ}$ período responda pelo 
PARA ONDE IR? A TRAJETÓRIA ELEITORAL DOS PREFEITOS DAS CAPITAIS ESTADUAIS BRASILEIRAS (1996-2014)

índice de $96,1 \%$ de permanência; no entanto, a tendência se manteve quando eles estavam no $2^{\circ}$ período, de modo que $73,8 \%$ optaram por cumpri-lo integralmente.

Dentre os 14 que não cumpriram o mandato por vontade própria, figura um que renunciou à prefeitura para ocupar cargo político (ministério) no último ano de seu 20 mandato e 13 que deixaram o cargo para concorrer a novo posto eletivo. Dentre estes, 12 preferiram concorrer a governador, um a senador e nenhum se dispôs a ser, por exemplo, deputado federal, cargo bastante procurado, como será demonstrado. No cálculo de oportunidades, parece claro que eles buscaram um cargo executivo de maior importância (governador), ocasionalmente um do legislativo hierarquicamente equivalente ao já ocupado (senador), o que confirma parcialmente a H3.

Há três deles que, em 10 mandato, arriscaram mais do que todos, pois sacrificaram não só dois anos de governo como também a perspectiva de um $2{ }^{\circ}$ período à frente do Executivo municipal. Todos preferiram concorrer a governador, um posto de maior importância política. Em comum, registravam passagens anteriores pela prefeitura e/ou por postos mais relevantes na hierarquia e usavam o cargo para retomar a carreira eletiva ou reiniciar a escalada em direção a postos mais altos.

Em se tratando de prefeitos em 20 mandato, há mais casos daqueles que renunciaram para concorrer (dez) e, portanto, em pouco tempo (seis anos) buscaram um 30 mandato, se for contabilizado aquele de prefeito a partir do qual ingressaram no universo pesquisado. Também há pontos em comum nesse grupo: nove com carreiras políticas antes de alcançar a prefeitura, entre as quais constava o cargo de deputado federal (seis) e a passagem anterior pela prefeitura (três). Porém, apenas um já havia ocupado o cargo pretendido. Aliás, desse contingente, somente mais um registrava a conquista de posto equivalente (senador).

Obviamente, eles consideraram que aquela era a melhor oportunidade para tal e, possivelmente, que poderia ser tarde se preferissem concluir o 20 mandato e concorrer tão somente após deixarem a prefeitura. Entre as circunstâncias que contribuíram para tal avaliação figuram não haver candidato à reeleição (dois casos) e o fato de o incumbent não ter vencido a disputa anterior (cinco casos). Logo, apenas três dos dez prefeitos inclusos nessa situação se dispuseram a enfrentar quem havia sido eleito no pleito anterior. A impulsionar essa disposição estava o fato de eles liderarem as intenções de voto no período pré-eleitoral, fruto dos bons índices de avaliação em suas gestões e do desgaste que os governadores enfrentavam. Apesar disso, apenas um deles conseguiu vencer. 
Tabela 3

Sucesso dos prefeitos das capitais estaduais que decidiram concorrer durante o mandato (Brasil, 1996-2014)*

\begin{tabular}{|l|c|c|c|c|c|c|}
\hline Cargo & \multicolumn{3}{|c|}{$\mathbf{2}^{\mathbf{0}}$ ano } & \multicolumn{3}{c|}{$\mathbf{4}^{\circ}$ ano } \\
\hline & $\mathbf{1 0}^{\mathbf{0}}$ mandato & $\mathbf{2}^{\mathbf{0}}$ mandato & Total & $\mathbf{1}^{\mathbf{0}}$ mandato & $\mathbf{2}^{\mathbf{0}}$ mandato & Total \\
\hline Governador & $\begin{array}{c}33,3 \\
(1)\end{array}$ & $\begin{array}{c}40,0 \\
(4)\end{array}$ & $\begin{array}{c}38,5 \\
(5)\end{array}$ & - & - & - \\
\hline Senador & - & 0 & 0 & - & - & - \\
\hline Prefeito & - & - & - & $\begin{array}{c}79,7 \\
(47)\end{array}$ & - & 79,7 \\
\hline Total & $\mathbf{( 3 )}$ & $\mathbf{( 1 0 )}$ & $\mathbf{( 1 3 )}$ & $\mathbf{( 5 9 )}$ & - & $\mathbf{( 5 9 )}$ \\
\hline
\end{tabular}

Fonte: TSE.

* Os valores estão expressos em percentual. Os números absolutos figuram entre parênteses.

A Tabela 3 apresenta o resultado obtido por esses prefeitos. A primeira parte traz as taxas de sucesso daqueles que decidiram concorrer no $2^{\circ}$ ano, portanto, em meio ao mandato. Ela aponta para uma reduzida taxa de sucesso em todas as situações: no geral $(38,5 \%)$, estejam em $10(33,3 \%)$ ou 20 mandato $(40 \%)$, tenham concorrido a governador ( $41,7 \%$ ou cinco em 12 casos) ou a senador (zero em uma ocorrência). Apesar de o $\mathrm{N}$ ser baixo, o que produz percentuais elevados baseados em poucos casos e recomenda não valorizá-los em demasia, o mais relevante está na tendência trazida pelos índices, que não corrobora, ao menos para esse subconjunto de prefeitos, a expectativa trazida pela $\mathrm{H} 4$.

A segunda parte da Tabela 3 aborda os que decidiram buscar a reeleição imediata (concorrer no $4^{\circ}$ ano). Houve $79,7 \%$ de sucesso, aproveitamento superior ao identificado por estudos sobre a reeleição de prefeitos no país (Barreto, 2009, 2014; Brambor e Ceneviva, 2012; Magalhães, 2012; Moreira, 2012) ${ }^{16}$. Por conseguinte, mostrou-se vantajoso pleitear a reeleição, bem como o alto risco de deixar o cargo em meio ao mandato para buscar outro, de tal modo que, mesmo aqueles que estavam em 20 mandato, preferiram não arriscar. Para estes, a H4 se confirma.

O foco agora se volta aos 14 prefeitos que fogem às expectativas, haja vista que não renunciaram para concorrer a outro cargo durante o mandato e tampouco pleitearam se reeleger. Contudo, as tabelas precedentes não têm capacidade para explicar esse comportamento, pois não permitem identificar outras peculiaridades que interferiram na decisão dos prefeitos. Por tais motivos, a análise a seguir tenta enquadrar os casos em categorias qualitativas. A explicação alusiva a cada uma é realizada na sequência.

\footnotetext{
16 Para estudos sobre a dinâmica das disputas em várias capitais, ver as coletâneas sobre os anos 2000 (Silveira, 2002) e 2008 (Baquero e Cremonese, 2009; Lavareda e Telles, 2011).
} 
Tabela 4

Motivo pelo qual os prefeitos das capitais estaduais não concorreram à reeleição nem pleitearam outro cargo (Brasil, 1996-2012)

\begin{tabular}{|l|c|c|}
\hline Motivo & N & \% \\
\hline Decisão própria & 6 & 42,9 \\
\hline Abandonou/Interrompeu a carreira eletiva & 5 & 35,7 \\
\hline Decisão partidária & 3 & 21,4 \\
\hline Total & $\mathbf{1 4}$ & $\mathbf{1 0 0}$ \\
\hline
\end{tabular}

Fonte: TSE.

Decisão própria - Refere-se a quem não pretendeu a reeleição, embora a legislação permitisse e a legenda estivesse disposta a apoiá-lo. Em última instância, a decisão foi do próprio prefeito e esteve circunscrita ao pleito em estudo. Obviamente, não quer dizer imotivada ou que não seja uma reação a constrangimentos políticos bem claros, percebidos pelo titular e, nesse sentido, não tão autônoma como a expressão possa evocar. A destacar que metade dessas desistências ocorreu no pleito de 2000, o que pode ser um indício de que elas cumpriam o acordo político firmado que levou os prefeitos a serem indicados candidatos, já que, em 1996, não era possível ao prefeito eleito em 1992 prosseguir no cargo.

Abandonou/Interrompeu a carreira eletiva - Implica não mais participar como candidato das eleições, a qual se sustenta para sempre ou por um longo período. As motivações decorrem de uma série de circunstâncias que, inclusive, podem contrariar a disposição do político. Apesar disso, é sempre uma escolha pessoal, visto que formalmente nada o obriga a se retirar das disputas ${ }^{17}$. Não se confunde com a categoria anterior ("decisão própria") porque aquela se refere a um pleito específico, mas a relação é evidente, pois pode ser o primeiro passo para o término da trajetória.

O critério para considerar que um político "abandonou/interrompeu" a carreira foi o fato de não disputar, no mínimo, três pleitos consecutivamente após deixar a prefeitura. Contudo, ele não serve para eleitos em 2008, pois, para estes, além da possibilidade de tentar reeleição, havia apenas mais um pleito disponível por ocasião da redação do artigo (2014). Para superar essa limitação foi preciso flexibilizar o critério e relacioná-lo com o momento vivido pelo político. Outra ponderação se refere ao fato de o foco estar no afastamento das disputas eleitorais, e não da política propriamente dita, pois muitos continuam na atividade, especialmente por meio de cargos de nomeação.

Decisão partidária - Situação em que o político tem a intenção de concorrer à reeleição, mas não é indicado pelo partido, logo, não houve desistência e, sim, por uma série de circunstâncias específicas, impedimento por decisão da legenda.

\footnotetext{
17 Aqueles que se afastaram por doença já foram excluídos, pois deixaram o cargo antes do período
} eleitoral. 


\section{As escolhas dos que completaram o mandato}

Esta seção está focada na decisão tomada no 10 pleito após o término do mandato pelos 45 prefeitos que o cumpriram integralmente. Eles também estão distinguidos entre os 14 que completaram um período e não concorreram à reeleição, e os 31 que cumpriram dois mandatos e não mais poderiam permanecer no cargo $^{18}$.

\section{Tabela 5 \\ Decisão tomada pelos prefeitos das capitais estaduais que completaram o mandato em relação ao $1^{\circ}$ pleito realizado após deixarem o cargo (Brasil, 1996-2014)*}

\begin{tabular}{|l|c|c|c|}
\hline Concorrer & $\mathbf{1 0}^{\mathbf{0}}$ mandato & $\mathbf{2}^{\circ}$ mandato & Total \\
\hline \multirow{2}{*}{ Sim } & 50,0 & 83,9 & 73,3 \\
& $(7)$ & $(26)$ & $(33)$ \\
\hline \multirow{2}{*}{ Não } & 50,0 & 16,1 & 26,7 \\
& $(7)$ & $(5)$ & $(12)$ \\
\hline \multirow{2}{*}{ Total } & $\mathbf{1 0 0}$ & $\mathbf{1 0 0}$ & $\mathbf{1 0 0}$ \\
& $\mathbf{( 1 4 )}$ & $\mathbf{( 3 1 )}$ & $\mathbf{( 4 5 )}$ \\
\hline
\end{tabular}

Fonte: TSE.

* Os valores estão expressos em percentual. Os números absolutos figuram entre parênteses.

A Tabela 5 mostra que a maioria $(73,3 \%)$ dos que encerraram o período à frente do Executivo municipal se apresentou na eleição subsequente, forte evidência de que a opção preferencial destes agora ex-prefeitos era obter um cargo eletivo no menor tempo possível. No entanto, esse comportamento é mais claro para quem cumpriu o $2^{\circ}$ período (84\%) do que para os que completaram o $1^{0}(50 \%)$, o que reforça que a decisão dos reeleitos de "honrar o mandato" recebido e de ficar algum tempo sem cargo eletivo fazia parte da estratégia para continuar na carreira.

No caso dos reeleitos, os dados também apontam que a permanência à frente da prefeitura por oito anos não se deu por falta de opções que justificassem a antecipação da saída, e sim como parte da construção de alternativas eleitorais a serem usufruídas após o término do mandato, o que reforça a necessidade de revisão da H3. Não é demasiado lembrar que, no curto período de tempo abarcado pelo artigo (dez anos), eles estão a buscar o $3^{\circ}$ mandato (os dois de prefeito conquistados mais o novo cargo). Já para os que não pleitearam a reeleição, as informações indicam que eles desistiram por questões circunstanciais, pois entre eles estão inclusos quatro dos seis que o fizeram por "decisão própria" e os três que não puderam concorrer por "decisão partidária".

\footnotetext{
18 Não há como analisar quatro casos, cujo $2^{\circ}$ período de governo, iniciado em 2013, ainda não havia se encerrado quando realizada esta análise. Eles não renunciaram para concorrer no $2^{\circ}$ ano desse mandato derradeiro.
} 
Tabela 6

Cargo pretendido pelos prefeitos das capitais estaduais que completaram o mandato em relação ao $1^{\circ}$ pleito realizado após deixarem o cargo (Brasil, 1996-2014)*

\begin{tabular}{|l|c|c|c|}
\hline Resultado & $\mathbf{1 0}^{\mathbf{0}}$ mandato & $\mathbf{2}^{\mathbf{0}}$ mandato & Total \\
\hline Governador & - & 23,1 & 18,2 \\
$(6)$ & 26,9 & 27,3 \\
Senador & 28,6 & $(7)$ & $(9)$ \\
\hline \multirow{2}{*}{ Deputado federal } & $(2)$ & 42,3 & 42,4 \\
& 42,8 & $(11)$ & $(14)$ \\
\hline \multirow{2}{*}{ Deputado estadual } & $(3)$ & 7,7 & 12,1 \\
& 28,6 & $(2)$ & $(4)$ \\
\hline \multirow{2}{*}{ Total } & $(2)$ & $\mathbf{1 0 0}$ & $\mathbf{1 0 0}$ \\
& $\mathbf{1 0 0}$ & $\mathbf{( 2 6 )}$ & $\mathbf{3 3}$ \\
\hline
\end{tabular}

Fonte: TSE.

* Os valores estão expressos em percentual. O número absoluto figura entre parênteses.

A Tabela 6 informa os cargos pretendidos por esses então ex-prefeitos. Seguindo o modelo de Miguel (2003), pode-se dizer que prepondera a intenção de "descer", pois $54,5 \%$ buscaram cargos de menor destaque (quatro concorreram a deputado estadual e 14 a federal), 27,3\% tentaram permanecer no mesmo patamar (senador) e 18,2\% quiseram ascender (governador). Na mesma medida, há o abrandamento da intenção de buscar cargo no Executivo (18,2\%), amplo predomínio dos postos legislativos $(81,8 \%)$ e daqueles cargos definidos por fórmula proporcional (54,5\%). Esses dados também parecem confirmar a interpretação proposta por Borchert (2011), pois se abrem diferentes trajetórias políticas, com perspectivas ascendentes e descendentes, atuação no plano estadual ou no plano nacional, confirmando a carreira "integrada".

O cargo individualmente mais cobiçado foi o de deputado federal $(42,4 \%)$. A impulsionar tal decisão, pondera-se ser praticamente garantida a indicação pelo partido, pois há várias vagas disponíveis, e, pela mesma razão, um lugar na Câmara dos Deputados pode ser alcançado com mais facilidade (ou menos dificuldades), especialmente para quem traz no currículo o comando da prefeitura da capital. As mesmas motivações valem para ser deputado estadual, embora o cargo tenha menos relevância em comparação tanto ao de prefeito quanto ao de deputado federal, o que ajuda a explicar por que é menos procurado $(12,1 \%)$.

Aqueles que pretendem ser governador ou senador devem superar dois obstáculos que tornam a empreitada mais desafiadora e, da mesma forma, valiosa. Um é a maior dificuldade para conseguir a indicação, haja vista que cada partido ou coligação só pode apresentar um candidato (dois no caso de senador a cada oito anos). Essas circunstâncias podem ensejar desgastantes disputas internas e/ou antecipadamente bloquear as pretensões desses ex-prefeitos, a depender do quadro de interessados ou da 
possibilidade de quem já está no cargo buscar a reeleição. O outro é o fato de serem eleições do tipo "o vencedor leva tudo", em que o risco de perder é muito maior, além de serem muito mais dispendiosas. Diante dessas dificuldades e com vistas a se manter na ativa, o posto de deputado federal se torna uma rota mais segura. No entanto, governador e senador somam $45,5 \%$ das candidaturas, a indicar uma "ambição" significativa desses ex-prefeitos, que encararam os riscos maiores associados a tais cargos. Não se pode esquecer que as personagens que se está a analisar venceram recentemente uma disputa (às vezes duas) semelhante a estas, o que pode credenciá-los a conquistar esses cargos de maior relevância política ou levá-los a se imaginar em condições disso.

Reflexo desses cálculos de oportunidade, a pretensão dos prefeitos que cumpriram o 20 mandato é maior. Nenhum dos sete que completou um mandato e não concorreu à reeleição buscou o cargo de governador, 71,4\% pleitearam ser deputado (federal, três, e estadual, dois) e $28,6 \%$ se lançaram a senador. No caso dos 26 prefeitos reeleitos, eles se dividiram de modo equitativo entre cargos escolhidos pela fórmula proporcional e aqueles escolhidos pela fórmula majoritária e, nesse caso, com prevalência dos que quiseram ser senador $(26,9 \%)$ em comparação aos que concorreram a governador $(23,1 \%)$. Apesar disso, o posto individualmente mais cobiçado é o de deputado federal $(42,3 \%)$, a exemplo do que ocorreu entre os que completaram um mandato. Por fim, dois concorreram a deputado estadual $(7,7 \%)$.

Tabela 7

Sucesso dos prefeitos das capitais estaduais que completaram o mandato e concorreram no $1^{\circ}$ pleito realizado após deixarem o cargo (Brasil, 1996-2014)*

\begin{tabular}{|l|c|c|c|}
\hline Cargo & $\mathbf{1 0}^{\mathbf{0}}$ mandato & $\mathbf{2}^{\mathbf{0}}$ mandato & Total \\
\hline Governador & - & $\begin{array}{c}16,7 \\
(1 / 6)\end{array}$ & $\begin{array}{c}16,7 \\
(1 / 6)\end{array}$ \\
\hline \multirow{2}{*}{ Senador } & 0 & 28,6 & 22,2 \\
& $(0 / 2)$ & $(2 / 7)$ & $(2 / 9)$ \\
\hline \multirow{2}{*}{ Deputado federal } & 0 & 63,6 & 50,0 \\
& $(0 / 3)$ & $(7 / 11)$ & $(7 / 14)$ \\
\hline \multirow{2}{*}{ Deputado estadual } & 50,0 & 0 & 25 \\
& $(1 / 2)$ & $(0 / 2)$ & $(1 / 4)$ \\
\hline \multirow{2}{*}{ Total } & $\mathbf{1 4 , 3}$ & $\mathbf{3 8 , 5}$ & $\mathbf{3 3 , 3}$ \\
& $\mathbf{( 1 / 7 )}$ & $\mathbf{( 1 0 / 2 6 )}$ & $\mathbf{( 1 1 / 3 3 )}$ \\
\hline
\end{tabular}

Fonte: TSE.

* Os valores estão expressos em percentual. O número absoluto figura entre parênteses.

A Tabela 7 apresenta um cenário negativo para os prefeitos que concorreram no pleito subsequente ao término do mandato, pois houve apenas um terço de sucesso. Logo, também para esses chefes do Executivo não se confirma a H4. O índice mostra a 
fragilidade deles, embora se manifeste mais intensamente entre os que completaram apenas um mandato $(14,3 \%)$ do que entre os que completaram dois mandatos $(38,5 \%)$.

A análise conforme o cargo pretendido também indica aproveitamento sempre reduzido. O melhor índice é registrado entre os que concorreram a deputado federal (50\%), a indicar a motivação pela qual este cargo é, também, o mais procurado. Seguem-se os que pleitearam ser deputado estadual $(25 \%)$, senador $(22,2 \%)$ e governador $(16,7 \%)$.

Se as mesmas informações forem distinguidas pelo número de mandatos completados, verifica-se que os prefeitos que cumpriram dois períodos tiveram mais sucesso entre os deputados federais $(63,6 \%)$, mas possuem desempenho fraco em todos os outros cargos: senador $(28,6 \%)$, governador $(16,7 \%)$ e, finalmente, deputado estadual, em que nenhum sucesso foi registrado em duas tentativas. Ao inverso, no caso dos prefeitos que cumpriram um mandato, o melhor aproveitamento figura entre os candidatos a deputado estadual (50\%), o pior entre os que pretenderam se tornar deputado federal e senador, em que só são registrados fracassos.

Tabela 8 Motivo pelo qual os prefeitos das capitais estaduais que completaram o mandato não concorreram no $1^{\circ}$ pleito realizado após deixarem o cargo (Brasil, 1996-2014)*

\begin{tabular}{|l|c|c|c|}
\hline Motivo & $\mathbf{1 0}^{\mathbf{0}}$ mandato & $\mathbf{2 0}^{\mathbf{0}}$ mandato & Total \\
\hline Decisão própria & $\begin{array}{c}28,6 \\
(2)\end{array}$ & $\begin{array}{c}40,0 \\
(2)\end{array}$ & $\begin{array}{c}33,3 \\
(4)\end{array}$ \\
\hline \multirow{2}{*}{ Abandonou/Interrompeu a carreira eletiva } & 71,4 & - & 41,7 \\
& $(5)$ & & $(5)$ \\
\hline \multirow{2}{*}{ Inelegibilidade } & - & 60,0 & 25,0 \\
& & $(3)$ & $(3)$ \\
\hline \multirow{2}{*}{ Total } & $\mathbf{1 0 0}$ & $\mathbf{1 0 0}$ & $\mathbf{1 0 0}$ \\
& $\mathbf{( 7 )}$ & $\mathbf{( 5 )}$ & $\mathbf{( 1 2 )}$ \\
\hline
\end{tabular}

Fonte: TSE.

* Os valores estão expressos em percentual. Os números absolutos figuram entre parênteses.

A Tabela 8 descreve a motivação dos 12 que não concorreram no pleito subsequente ao término do mandato e que, por isso, ampliaram o tempo mínimo em que ficaram sem mandato eletivo. No caso dos que cumpriram apenas um mandato e não concorreram à reeleição, os dados confirmam o que a análise já apontara: entre eles figuram os cinco $(71,4 \%)$ que foram identificados como os que abandonaram a carreira política - e não poderia deixar de ser, caso contrário a classificação anterior não se mostraria correta -, aos quais se somam dois que o fizeram por "decisão própria" $(28,6 \%)$. Dentre os que cumpriram o $2^{\circ}$ mandato, nenhum abandonou a carreira eletiva e eles continuaram afastados das urnas por "decisão própria" (40\%), que já foi 
apresentada, e por "inelegibilidade" (60\%), que se refere a prefeitos que deixaram de concorrer porque foram impedidos em razão da Lei da Ficha Limpa.

\section{As decisões dos que foram derrotados na tentativa de reeleição}

Esta seção se dedica a analisar o caso dos 12 prefeitos que tentaram a reeleição, mas foram derrotados nas urnas e, embora não o desejassem, acabaram por cumprir apenas um mandato, a exemplo daqueles que não se apresentaram para um novo período consecutivo de governo. Apesar do revés eleitoral, esses ex-prefeitos tinham condições de, passados dois anos, novamente se apresentar às urnas, de modo semelhante ao ocorrido com os prefeitos que completaram um ou dois mandatos.

\section{Tabela 9}

Decisão tomada pelos prefeitos das capitais estaduais no $1^{\circ}$ pleito realizado após não conseguirem a reeleição (Brasil, 1996-2014)

\begin{tabular}{|l|c|c|}
\hline Concorrer & $\mathbf{N}$ & \% \\
\hline Sim & 10 & 83,3 \\
\hline Não & 2 & 16,7 \\
\hline Total & $\mathbf{1 2}$ & $\mathbf{1 0 0}$ \\
\hline
\end{tabular}

Fonte: TSE.

A Tabela 9 mostra que a derrota na tentativa de reeleição não afastou das urnas os agora ex-prefeitos, pois $83,3 \%$ aproveitaram o $1^{\circ}$ pleito subsequente para voltar a apresentar-se ao eleitorado. Os dois que continuaram distante das urnas o fizeram por "decisão própria".

Tabela 10

Cargo pretendido e taxa de sucesso dos prefeitos das capitais estaduais que concorreram no $1^{\circ}$ pleito realizado após serem derrotados na tentativa de reeleição (Brasil, 1996-2014)

\begin{tabular}{|l|c|c|c|}
\hline Cargo & Sucesso & Candidatura & Taxa (\%) \\
\hline Governador & 0 & 1 & 0 \\
\hline Senador & 1 & 1 & 100 \\
\hline Deputado federal & 6 & 6 & 100 \\
\hline Vice-governador & 1 & 2 & 50,0 \\
\hline Total & $\mathbf{8}$ & $\mathbf{1 0}$ & $\mathbf{8 0 , 0}$ \\
\hline
\end{tabular}

Fonte: TSE. 
A Tabela 10 mostra que é alto o índice de sucesso (80\%) e confirma, para eles, a $\mathrm{H} 4^{19}$. Contudo, a derrota sofrida no pleito municipal pode se manifestar no elenco dos cargos pretendidos, pois seis optaram por concorrer a deputado federal, considerado por Miguel (2003) como cargo menos relevante do que o anteriormente ocupado, e um a senador, de importância equivalente. Dois se apresentaram a vice-governador, posto que surgiu pela primeira vez nas pretensões dos atores investigados, e um a governador.

Igualmente, é possível analisar o índice de sucessos desses prefeitos por cargo pretendido. Destaca-se o acerto daqueles que buscaram um lugar na Câmara dos Deputados: os seis se elegeram, o mesmo tendo ocorrido com aquele que concorreu a senador. Dentre os que tentaram ser vice-governador, houve $50 \%$ de sucesso e, para o que concorreu a governador, zero 20 .

\section{Visão geral}

Os dados levantados podem ser justapostos para permitir uma comparação mais direta entre a decisão de concorrer, o cargo pretendido, o resultado alcançado e a situação particular em que cada prefeito se encontrava.

\section{Quadro 2}

\section{Candidatura dos prefeitos das capitais estaduais conforme a situação em que se encontravam (Brasil, 1996-2014)}

\begin{tabular}{|l|c|c|c|}
\hline Situação & Candidatos & Total & Taxa (\%) \\
\hline Não voltou a concorrer & 8 & 77 & 10,4 \\
\hline Voltou a concorrer & 69 & 77 & 89,6 \\
\hline Renunciou no 20 ano do 10 mandato para concorrer & 3 & 62 & 4,8 \\
\hline Concorreu à reeleição & 59 & 73 & 80,8 \\
\hline Renunciou no 20 ano do 20 mandato para concorrer & 10 & 46 & 21,7 \\
\hline Não buscou a reeleição (10 pleito subsequente) & 7 & 14 & 50,0 \\
\hline Derrotado na reeleição (10 pleito subsequente) & 10 & 12 & 83,3 \\
\hline Reeleito (10 pleito após o término do mandato) & 26 & 31 & 83,9 \\
\hline
\end{tabular}

Fonte: Elaboração própria a partir de dados do TSE.

Ao considerar os 77 prefeitos inclusos no artigo, verifica-se que 69 ou $89,6 \%$ voltaram a se apresentar às urnas no espaço de tempo abarcado pelo artigo, o que corrobora a H1. Dentre os $10,4 \%$ que não voltaram a concorrer (oito casos), figuram: um que, tendo renunciado ao cargo por motivo de saúde no $1^{\circ}$ mandato, faleceu logo depois e não teve, de fato, como optar pela continuidade na carreira; os cinco que abandonaram/interromperam a participação em eleições; os dois que deixaram o cargo

\footnotetext{
${ }^{19} \mathrm{O}$ índice de sucesso pode chegar a $90 \%$, se for considerado o caso do candidato a governador que foi contabilizado como derrota, mas que, dois anos depois, foi empossado no cargo, após o TSE cassar o mandato do então titular (Folha de S. Paulo, 11 nov. 2004).

${ }^{20}$ Pode passar a $100 \%$ se for considerada a situação narrada na nota anterior.
} 
em 2012 e por "vontade própria" não pleitearam a reeleição e não voltaram a se apresentar, embora ainda não seja possível classificá-los como "aposentados".

O Quadro 2 também demonstra que houve vinculação entre a maior disposição de se apresentar imediatamente ao eleitor e não estar em exercício do mandato e/ou restar menos tempo de permanência no cargo. Poucos são os prefeitos que buscaram um novo posto quando exerciam a função, sendo tal disposição menor entre os que estavam em 10 mandato do que entre os que se encontravam em 20 (4,8\% e 21,7\%, respectivamente). Quando o mandato estava para se encerrar ou já havia se encerrado, a taxa de apresentação no 10 pleito subsequente cresceu significativamente: $80,8 \%$ dentre os que poderiam concorrer à reeleição, $83,3 \%$ dentre os que foram derrotados na tentativa de reeleição e $83,9 \%$ dentre os que completaram o 20 mandato. 0 comportamento que fica a meio caminho entre essas situações é daqueles que não concorreram à reeleição, pois $50 \%$ se apresentaram. Contudo, se desse contingente forem excluídos os que não o fizeram porque abandonaram a carreira política, há $78 \%$ de candidatura entre os que, de fato, ainda tinham disposição para tal, o que se aproxima bastante do comportamento dos demais.

Tabela 11

Cargo escolhido pelos prefeitos das capitais estaduais que se candidataram conforme a situação em que se encontravam (Brasil, 1996-2014)*

\begin{tabular}{|c|c|c|c|c|c|c|c|c|c|}
\hline \multirow[t]{2}{*}{ Situação } & \multicolumn{4}{|c|}{ Cargo } & & \multicolumn{3}{|c|}{ Relevância do cargo } & \multirow[t]{2}{*}{ Total } \\
\hline & Gov. & VG & Sen. & DF & DE & $>$ & $=$ & $<$ & \\
\hline $\begin{array}{l}\text { Renunciou no } 2^{\circ} \text { ano do } 1^{\circ} \\
\text { mandato }\end{array}$ & $\begin{array}{l}100 \\
(3)\end{array}$ & - & - & - & - & $\begin{array}{l}100 \\
(3)\end{array}$ & - & - & $\begin{array}{l}100 \\
(3)\end{array}$ \\
\hline $\begin{array}{l}\text { Renunciou no } 2^{\circ} \text { ano do } 2^{\circ} \\
\text { mandato }\end{array}$ & $\begin{array}{c}90,0 \\
(9)\end{array}$ & & $\begin{array}{c}10,0 \\
(1)\end{array}$ & & - & $\begin{array}{c}90,0 \\
(9)\end{array}$ & $\begin{array}{c}10,0 \\
(1)\end{array}$ & - & $\begin{array}{l}100 \\
(10)\end{array}$ \\
\hline $\begin{array}{l}\text { Não buscou a reeleição } \\
\text { (10 pleito subsequente) }\end{array}$ & - & - & $\begin{array}{c}28,6 \\
(2)\end{array}$ & $\begin{array}{c}42,8 \\
(3) \\
\end{array}$ & $\begin{array}{c}28,6 \\
(2)\end{array}$ & - & $\begin{array}{c}28,6 \\
(2)\end{array}$ & $\begin{array}{c}71,4 \\
(5) \\
\end{array}$ & $\begin{array}{l}100 \\
(7)\end{array}$ \\
\hline $\begin{array}{l}\text { Derrotado na reeleição } \\
\left(1^{\circ} \text { pleito subsequente) }\right.\end{array}$ & $\begin{array}{c}10,0 \\
(1)\end{array}$ & $\begin{array}{c}20,0 \\
(2)\end{array}$ & $\begin{array}{c}10,0 \\
(1)\end{array}$ & $\begin{array}{c}60,0 \\
(6)\end{array}$ & - & $\begin{array}{c}30,0 \\
(3)\end{array}$ & $\begin{array}{c}10,0 \\
(1)\end{array}$ & $\begin{array}{c}60,0 \\
(6)\end{array}$ & $\begin{array}{l}100 \\
(10)\end{array}$ \\
\hline $\begin{array}{l}\text { Reeleito ( } 10 \text { pleito após } \\
\text { término do mandato) }\end{array}$ & $\begin{array}{c}23,1 \\
(6)\end{array}$ & - & $\begin{array}{c}26,9 \\
(7)\end{array}$ & $\begin{array}{l}42,3 \\
(11)\end{array}$ & $\begin{array}{l}7,7 \\
(2)\end{array}$ & $\begin{array}{c}23,1 \\
(6)\end{array}$ & $\begin{array}{c}26,9 \\
(7)\end{array}$ & $\begin{array}{l}50,0 \\
(13)\end{array}$ & $\begin{array}{l}100 \\
(26)\end{array}$ \\
\hline Total & $\begin{array}{l}33,9 \\
(19)\end{array}$ & $\begin{array}{l}3,6 \\
(2)\end{array}$ & $\begin{array}{l}19,6 \\
(11)\end{array}$ & $\begin{array}{l}35,7 \\
(20)\end{array}$ & $\begin{array}{l}7,2 \\
(4)\end{array}$ & $\begin{array}{l}37,5 \\
(21)\end{array}$ & $\begin{array}{l}19,6 \\
(11)\end{array}$ & $\begin{array}{l}42,9 \\
(24)\end{array}$ & $\begin{array}{l}100 \\
(56)\end{array}$ \\
\hline
\end{tabular}

Fonte: Elaboração própria a partir de dados do TSE.

Gov. (Governador); VG (Vice-Governador); Sen. (Senador); DF (Deputado Federal); DE (Deputado Estadual)

* Os valores estão expressos em percentual. Os números absolutos figuram entre parênteses.

A Tabela 11 mostra que, quanto mais cedo o prefeito deixar o cargo para concorrer, mais importante ou valioso será o posto pretendido; quanto pior a situação em que ele deixa o cargo, menos importante será aquele pretendido ao se apresentar no 
PARA ONDE IR? A TRAJETÓRIA ELEITORAL DOS PREFEITOS DAS CAPITAIS ESTADUAIS BRASILEIRAS (1996-2014)

10 pleito subsequente ${ }^{21}$. Assim, os que o abandonaram em meio ao mandato pretenderam cargos de maior importância (governador, em 92,3\% dos casos ou 12 dos 13 pretendentes) e, residualmente, de igual relevância (senador, um caso ou 7,7\%). Novamente, os que o fizeram no 10 mandato são mais "ambiciosos" do que os que o realizaram no $2^{\circ}$ ( $100 \%$ e $90 \%$ concorreram a governador, respectivamente).

Entre os que se candidataram após deixar a prefeitura, além de figurarem cargos não pretendidos pelos anteriores, destaca-se a intenção de se tornar deputado federal (de $42,3 \%$ a $60 \%$ ). Também há diferenças entre eles: (1) os que não disputaram a reeleição e completaram apenas um mandato buscaram menos cargos (senador, deputado federal e estadual) e não incluíram o mais alto (governador); (2) os que tentaram sem sucesso a reeleição e, assim como os anteriores, cumpriram um mandato ampliaram o elenco (governador, senador, deputado federal e vice-governador), pretenderam cargo mais alto (governador, 10\%) e ampliaram a intensidade da preferência por um lugar na Câmara de Deputados (60\%); (3) os que completaram dois mandatos preferiram o mesmo número de cargos que os da situação precedente, mas não há concorrentes a vice-governador, que são substituídos por pretendentes a deputado estadual - ou seja, todos quiseram cargos de "titular" - e ambicionaram mais intensamente ser governador $(23,1 \%)$.

Tabela 12

Taxa de sucesso dos prefeitos das capitais estaduais conforme a situação em que se encontravam (Brasil, 1996-2014)

\begin{tabular}{|l|c|c|c|}
\hline Situação & Sucesso & Candidatura & Taxa (\%) \\
\hline Concorreu à reeleição & 47 & 59 & 79,7 \\
\hline Renunciou no $2^{\circ}$ ano do $1^{\circ}$ mandato & 1 & 3 & 33,3 \\
\hline Renunciou no $2^{\circ}$ ano do $2^{\circ}$ mandato & 4 & 10 & 40,0 \\
\hline Derrotado na reeleição (10 pleito subsequente) & 8 & 10 & 80,0 \\
\hline Não buscou a reeleição (10 pleito subsequente) & 1 & 7 & 14,3 \\
\hline Reeleito (10 pleito após término do mandato) & 10 & 26 & 38,5 \\
\hline Total & $\mathbf{7 1}$ & $\mathbf{1 1 5}$ & $\mathbf{6 2 , 7}$ \\
\hline
\end{tabular}

Fonte: Elaboração própria a partir de dados do TSE.

A Tabela 12 compara as taxas de sucesso dos prefeitos conforme as situações em que se encontravam. O índice geral de sucesso ao buscar o próximo mandato é de $62,7 \%$, o que confirma a $\mathrm{H} 4$. Todavia, se os vencedores na tentativa de reeleição forem retirados (47 em 59 ocorrências) e a taxa incluir apenas os que tentaram um cargo diferente daquele já ocupado, o aproveitamento cai para 42,9\% (24 cargos distintos obtidos em 56 tentativas).

21 Obviamente, a exceção está entre os que concorreram à reeleição, que buscaram na totalidade a manutenção do posto já ocupado, razão pela qual não figuram na Tabela 11. 
A comparação também evidencia que a taxa de sucesso varia conforme a situação em que o prefeito se encontrava, o que permite tornar ainda mais preciso o resultado alcançado. E, nesse caso, há algo surpreendente nas informações: quando concorreram no pleito imediatamente subsequente, os mais bem-sucedidos foram os derrotados ao buscar a reeleição, com $80 \%$ (apenas os que concorrem ao 20 mandato consecutivo têm performance similar ao atingirem $79,7 \%$ ). Os prefeitos reeleitos - os que alcançaram o que os anteriores não obtiveram - foram mais punidos nas urnas ao pretenderem um novo cargo, pois obtiveram entre $40 \%$ de sucesso (os que deixaram o Executivo municipal em meio ao mandato) e 38,5\% (os que completaram os dois períodos $)^{22}$. Situação pior vivenciaram os que abandonaram o cargo na metade do 10 mandato, cujo sucesso atingiu 33,3\%. Mas os menos bem-sucedidos foram os que não se lançaram à reeleição, consagrados em apenas $14,3 \%$ no $1^{\circ}$ pleito subsequente, o que reforça a perspectiva de serem figuras políticas em situação de desprestígio junto ao eleitorado e/ou ao próprio partido e lança luzes sobre as razões pelas quais não procuraram continuar na prefeitura.

Tabela 13

Taxa de sucesso dos prefeitos das capitais estaduais conforme o cargo escolhido e a situação em que se encontravam (Brasil, 1996-2014)*

\begin{tabular}{|c|c|c|c|c|c|c|c|c|c|}
\hline \multirow[t]{2}{*}{ Situação } & \multicolumn{5}{|c|}{ Cargo } & \multicolumn{3}{|c|}{ Relevância do cargo } & \multirow[t]{2}{*}{ Total } \\
\hline & Gov. & VG & Sen. & DF & DE & $>$ & $=$ & $<$ & \\
\hline $\begin{array}{l}\text { Renunciou no } 2^{\circ} \text { ano do } \\
1^{\circ} \text { mandato }\end{array}$ & $\begin{array}{l}33,3 \\
(1 / 3)\end{array}$ & - & - & - & - & $\begin{array}{l}33,3 \\
(1 / 3)\end{array}$ & - & - & $\begin{array}{l}33,3 \\
(1 / 3)\end{array}$ \\
\hline $\begin{array}{l}\text { Renunciou no } 2^{\circ} \text { ano do } \\
2^{\circ} \text { mandato }\end{array}$ & $\begin{array}{l}44,4 \\
(4 / 9)\end{array}$ & - & $\begin{array}{c}0 \\
(0 / 1)\end{array}$ & - & - & $\begin{array}{l}44,4 \\
(4 / 9)\end{array}$ & $\begin{array}{c}0 \\
(0 / 1)\end{array}$ & - & $\begin{array}{c}40,0 \\
(4 / 10)\end{array}$ \\
\hline $\begin{array}{l}\text { Derrotado na reeleição } \\
\text { (10 pleito subsequente) }\end{array}$ & $\begin{array}{c}0 \\
(0 / 1)\end{array}$ & $\begin{array}{l}50,0 \\
(1 / 2)\end{array}$ & $\begin{array}{c}100 \\
(1 / 1)\end{array}$ & $\begin{array}{c}100 \\
(6 / 6)\end{array}$ & - & $\begin{array}{l}33,3 \\
(1 / 3)\end{array}$ & $\begin{array}{c}100 \\
(1 / 1)\end{array}$ & $\begin{array}{c}100 \\
(6 / 6)\end{array}$ & $\begin{array}{c}80,0 \\
(8 / 10) \\
\end{array}$ \\
\hline $\begin{array}{l}\text { Não buscou a reeleição } \\
\text { (10 pleito subsequente) }\end{array}$ & - & - & $\begin{array}{c}0 \\
(0 / 2) \\
\end{array}$ & $\begin{array}{c}0 \\
(0 / 3) \\
\end{array}$ & $\begin{array}{l}50,0 \\
(1 / 2) \\
\end{array}$ & - & $\begin{array}{c}0 \\
(0 / 2) \\
\end{array}$ & $\begin{array}{l}20,0 \\
(1 / 5) \\
\end{array}$ & $\begin{array}{l}14,3 \\
(1 / 7) \\
\end{array}$ \\
\hline $\begin{array}{l}\text { Reeleito ( } 1^{\circ} \text { pleito após } \\
\text { término mandato) }\end{array}$ & $\begin{array}{l}16,7 \\
(1 / 6)\end{array}$ & - & $\begin{array}{l}28,6 \\
(2 / 7)\end{array}$ & $\begin{array}{c}63,6 \\
(7 / 11)\end{array}$ & $\begin{array}{c}0 \\
(0 / 2)\end{array}$ & $\begin{array}{l}16,7 \\
(1 / 6)\end{array}$ & $\begin{array}{l}28,6 \\
(2 / 7)\end{array}$ & $\begin{array}{c}53,8 \\
(7 / 13)\end{array}$ & $\begin{array}{c}38,5 \\
(10 / 26)\end{array}$ \\
\hline Total & $\begin{array}{c}31,6 \\
(6 / 19)\end{array}$ & $\begin{array}{c}50,0 \\
(1 / 2)\end{array}$ & $\begin{array}{c}27,3 \\
(3 / 11)\end{array}$ & $\begin{array}{c}65,0 \\
(13 / 20)\end{array}$ & $\begin{array}{c}25,0 \\
(1 / 4)\end{array}$ & $\begin{array}{c}33,3 \\
(7 / 21)\end{array}$ & $\begin{array}{c}27,3 \\
(3 / 11)\end{array}$ & $\begin{array}{c}58,3 \\
(14 / 24)\end{array}$ & $\begin{array}{c}43,9 \\
(24 / 56)\end{array}$ \\
\hline
\end{tabular}

Fonte: Elaboração própria a partir de dados do TSE.

Gov. (Governador); VG (Vice-Governador); Sen. (Senador); DF (Deputado Federal); DE (Deputado Estadual)

* Os valores estão expressos em percentual. Os números absolutos figuram entre parênteses.

Com a Tabela 13 é possível comparar a taxa de sucesso por cargo pretendido. Os dados evidenciam que, com exceção do posto de prefeito (em que o êxito na reeleição

22 Cabe destacar que os vices que assumiram a titularidade e conquistaram nas urnas 020 mandato apresentaram maior fragilidade do que aqueles que foram duas vezes eleitos prefeito: todos os vices foram derrotados (cinco tentativas), enquanto os segundos alcançaram $48 \%$ de sucesso (10 em 21 casos). 
atinge 79,7\% - Tabela 12), o mais "seguro" (ou menos arriscado) foi o de deputado federal, com $65 \%$ de tentativas bem-sucedidas. Todos os demais trazem a igualdade de resultado ou o predomínio de insucessos: vice-governador $(50 \%)$, governador $(31,6 \%)$, senador $(27,3 \%)$ e deputado estadual (25\%). As informações mais surpreendentes dizem respeito ao cargo de deputado estadual, que se mostrou o mais arriscado de todos, quando deveria ser o mais acessível, pois tem menos importância do que o de prefeito, apresenta grande oferta de vagas e é definido por fórmula proporcional. Em contraste, a mais alta taxa foi registrada entre os candidatos ao cargo de deputado federal, que segue o mesmo princípio, possui maior relevância e tem menos vagas disponíveis, de modo a ser, em teoria, de mais difícil obtenção.

É possível reagrupar as informações conforme a importância do cargo e o poder em que é exercido. Verifica-se que a taxa de sucesso tem dois comportamentos: para os de igual ou maior importância (governador, senador e vice-governador), que também são aqueles de fórmula majoritária, ela gira em torno de $30 \%$, mas sobe para quase o dobro (53,8\%), em se tratando de cargos de menor importância (deputados federal e estadual), definidos via sistema proporcional. Mas, como indicado acima, a distinção efetiva é entre o cargo de deputado federal e os demais, pois o sucesso entre os que pleiteiam ser deputado estadual também fica próximo a $30 \%$ (25\%, em termos precisos).

\section{Conclusão}

Tendo em vista existir um limite temporal para a permanência como chefe do Executivo (dois mandatos ou oito anos), o artigo procurou identificar as decisões quanto ao passo seguinte da carreira eletiva tomadas pelos prefeitos das capitais estaduais de 1996 a 2008, em um total de 77 casos. A intenção foi verificar a presença de alguma tendência predominante nessas escolhas (candidaturas, cargos procurados e resultados alcançados).

A H1 era de que, por conta da importância do posto, esses prefeitos procurariam dar continuidade à carreira eleitoral. Ela foi comprovada, pois 69 deles ou $89,6 \%$ voltaram a concorrer, seja à reeleição imediata, seja a outro cargo. A H2 também se confirmou plenamente: quando os prefeitos estavam em $1^{0}$ mandato, eles não renunciaram para concorrer a outro cargo, pois deram preferência a tentar a reeleição imediata ( $80,8 \%$ ou 59 em 73 situações).

No entanto, a $\mathrm{H} 3$ não se revelou correta: os prefeitos em 20 período não renunciaram para concorrer a outro cargo, ao contrário, a ampla maioria $(78,3 \%$ ou 36 em 46 ocorrências) preferiu completar o mandato, ainda que ao custo de ficar sem posto eletivo. Todavia, aqueles que abriram mão do cargo ( $21,7 \%$ ou 10 casos) concorreram a posto de maior importância (governador) - excepcionalmente de senador (um caso) - a apontar que apenas a "ambição progressiva" justificou abrir mão de um mandato já alcançado, ainda que prestes a se encerrar de modo inexorável. Também foram 
encontrados casos de prefeitos que renunciaram já no $1^{\circ}$ mandato - residuais, três em 62 possibilidades ou $4,8 \%$-, o que confirma ainda mais fortemente a perspectiva, pois todos concorreram a governador. Embora não formem a maioria, como sugeria a $\mathrm{H} 3$, a ampliação no índice de prefeitos que renunciaram no $2^{\circ}$ mandato indica que o término do período como prefeito produz efeitos e estimula a buscar de imediato outro cargo.

As situações identificadas acima remetem à $\mathrm{H} 4$, que apontava para a expectativa de os prefeitos alcançarem taxas de sucesso elevadas ao buscarem um novo mandato. De fato, dos 69 que tentaram, apenas 17,4\% (12 casos) não o conquistaram no período analisado - que compreende no máximo o $1^{\circ}$ pleito realizado após o término do período à frente da prefeitura -, ou seja, a maioria $(82,6 \%)$ voltou a ser consagrada nas urnas ${ }^{23}$. No entanto, quando esses dados são desagregados, verifica-se um cenário mais matizado. A reeleição é uma realidade para a maioria deles $(79,7 \%$ ou 47 em 59 tentativas), mas o aproveitamento cai para 43,9\% (24 em 56 casos) se eles pleiteiam um novo cargo, isto é, há mais derrotas do que vitórias. Logo, se o novo mandato implicar outro cargo, não se pode falar da mesma performance. E os dados trazem algumas surpresas: os prefeitos que fracassaram na tentativa de reeleição alcançaram desempenho semelhante ao dos que buscaram conquistar um $2^{\circ}$ período à frente do Executivo municipal ( $80 \%$ ou oito sucessos em dez tentativas). Ao contrário, os que foram reeleitos atingiram 38,5\% (dez em 26 ocorrências) e os que sequer tentaram a reeleição à prefeitura, $14,3 \%$ (apenas um êxito em sete casos).

Cabe relatar que os prefeitos analisados alcançaram no período 71 novos mandatos. Destes, praticamente dois terços era um $2^{\circ}$ período na prefeitura $(66,2 \%$ ou 47) e o terço restante, outros cargos (33,8\% ou 24). Dentre estes prepondera o de deputado federal ( $54,2 \%$ ou 13 ), seguindo-se o de governador ( $25 \%$ ou seis), o de senador $(12,5 \%$ ou 3$)$ e os de deputado estadual e de vice-governador $(4,2 \%$ ou um cada). Percebe-se que há o predomínio de postos legislativos $(71,5 \%)$, especialmente aqueles definidos por fórmula proporcional e de menor relevância (58,3\%), conforme a hierarquia proposta por Miguel (2003). Porém, cargos do Executivo e de maior relevância não podem ser menosprezados $(29,2 \%)$, pois indicam que uma parcela razoável dos prefeitos das capitais estaduais galgou postos mais elevados na hierarquia (governador e vice-governador) em pouco tempo (no $1^{\circ}$ pleito após deixar a prefeitura ou, no máximo, dez anos após se tornarem prefeitos, recorte temporal do artigo).

No cômputo geral, 20 dos 77 prefeitos analisados acumularam esse cargo por um mandato (26\%), 33 foram reeleitos e alcançaram um 20 período $(42,9 \%)$, de forma que 53 ou $68,8 \%$ ocuparam tão somente essa chefia do Executivo. Porém, há dez (13\%) que agregaram um segundo cargo (governador, vice-governador, senador, deputado estadual, todos com um caso, e de deputado federal, com seis ocorrências). E, ainda, os que obtiveram um $2^{\circ}$ mandato de prefeito e também um outro cargo: cinco ou $6,5 \%$ se

\footnotetext{
${ }^{23}$ Pode-se destacar que sete desses 12 alcançaram novos mandatos para além do recorte temporal aqui adotado e se tornaram: governador (2), senador (1), deputado federal (1), deputado estadual (1) e vereador (2), a confirmar, mais uma vez, a carreira "integrada" vaticinada por Borchert.
} 
PARA ONDE IR? A TRAJETÓRIA ELEITORAL DOS PREFEITOS DAS CAPITAIS ESTADUAIS BRASILEIRAS (1996-2014)

tornaram governador e são os mais bem-sucedidos dentre todos; dois ou 2,6\%, senador; sete ou $9,1 \%$, deputado federal.

Ao relacionar as tendências identificadas no artigo com o debate sobre o tema, o primeiro destaque é o fato de os prefeitos das capitais estaduais escolherem diferentes trajetórias de continuidade na atividade política eletiva. Conforme o parâmetro de classificação fornecido por Miguel (2003), elas incluem a pretensão de "subir" ou de "descer" nessa hierarquia, assim como a de amealhar cargos de importância equivalente. O mesmo pode ser dito se o critério for aquele adotado por Samuels (2003), baseado no nível da federação e no poder pretendido: os prefeitos se propõem a deixar o âmbito local, mas tanto buscam permanecer no plano estadual quanto "ascender" a Brasília, continuar em cargo executivo ou passar ao legislativo (estadual ou nacional e, nesse caso, na Câmara alta ou baixa).

Diante de tantas possibilidades de trajetória oferecidas pela estrutura de oportunidades no país e de percursos efetivamente realizados, o que impede a identificação de um caminho único, os resultados alcançados reforçam a limitação desse modo de conceber e consequentemente de analisar a carreira política no Brasil, assim como enfatizam a procedência da classificação sugerida por Borchert $(2009,2011)$. O autor afirma que não há uma hierarquia claramente estabelecida entre os cargos, pois são oferecidos em diferentes níveis da federação (municipal, estadual, federal) e de poder (Executivo e Legislativo), definidos a partir de fórmulas eleitorais distintas, em diferentes, porém curtas, temporalidades (a cada dois anos). Nesse modelo, a escolha do cargo pretendido, seja ele alcançado ou não, não está submetida a uma trajetória única a ser percorrida inexoravelmente. Logo, classificações como a de Miguel (2003), adotada pelo artigo, servem de importante referência para dimensionar esses percursos, mais do que como base para fixar caminhos obrigatórios.

Os resultados do artigo também permitem verificar que, apesar das diferentes escolhas realizadas pelos prefeitos, a permanência nesse cargo por mais um período (ou seja, a reeleição) destaca-se como a primeira opção. O fato de a maioria não ter conseguido ou buscado outro cargo no período estudado - no máximo dez anos após chegar à prefeitura - reforça o caráter local desses atores, apesar de eles terem alcançado um cargo relevante na política estadual.

Por fim, outro achado do artigo mostra que a opção preferencial dos prefeitos, quando se torna inevitável deixar o cargo - por completar dois mandatos consecutivos, não concorrer à reeleição ou ter sido derrotado na tentativa -, é concorrer ao cargo de deputado federal, também este o posto eletivo em que há maior taxa de sucesso. Tal resultado corrobora as afirmações de Figueiredo e Limongi (1996), F. Santos (2000) e Oliveira (2009), segundo as quais o Legislativo federal não deve ser concebido simplesmente como uma opção menor no elenco à disposição dos políticos, refúgio para aqueles que não conseguem cargos executivos, como destacado por Samuels (2003), e sim como parte da carreira política, especialmente quando ela é concebida de modo dinâmico, em que a regra é a obtenção ou a busca de diferentes cargos, com vistas à 
manutenção na atividade. Essa concepção, mais uma vez, reforça a ideia de que os políticos "circulam" por distintos cargos, de diferentes poderes e âmbitos da federação o que F. Santos (2000) chamou de "efeito zigue-zague". Na mesma medida, essas informações reforçam a capacidade de atração do parlamento e o papel relevante que ele desempenha como parte da carreira política, ainda que o comportamento dos políticos não seja caracterizado por carreiras exclusivamente parlamentares.

Alvaro Augusto de Borba Barreto - Doutor em História, professor do PPG em Ciência Política, no Instituto de Filosofia, Sociologia e Política da Universidade Federal de Pelotas (Ifisp-UFPel). E-mail: <albarret.sul@gmail.com>.

\section{Referências bibliográficas}

\section{Citadas no texto}

ARAujo, S. C. "A renovação parlamentar no Brasil". Dissertação de Mestrado em Ciência Política. Iuperj, Rio de Janeiro 2002.

BAqueRo, M.; CREMOneSE, D. (orgs.). Eleições municipais 2008 - uma análise do comportamento eleitoral brasileiro. Ijuí: Unijuí, 2009.

BARRETO, A. "Reeleição para o Executivo municipal no Brasil (2000-2008)". Debates, Porto Alegre, vol. 3, n², p. 97-115, jul.-dez. 2009.

. "Destinos cruzados: partidos e candidatos nas eleições para prefeito no Brasil e intendente no Uruguai (2000-2012)". Debates, Porto Alegre, vol. 8, n 1, p. 105-125, jan.-abr. 2014.

BLACK, G. S. "A theory of political ambition: career choice and the role of structural incentives". American Political Science Review, vol. 66, n 1, p. 144-159, mar. 1972.

BORCHERT, J. "Ambition and opportunity in federal systems: the political sociology of political career patterns in Brazil, Germany and the United States". Universidade de Frankfurt, 2009. Disponível em: <http://papers.ssrn.com/sol3/papers.cfm?abstract_id=1450640>. Acesso em: 10 out. 2013.

. "Individual ambition and institutional opportunity: a conceptual approach to political careers in multi-level systems". Regional \& Federal Studies, vol. 21, n² 2, p. 117-140, 2011.

Botero, F.; RenNó, L. "Career choice and legislative reelection - evidence from Brazil and Colombia". Brazilian Political Science Review, São Paulo, vol. 1, n 1, p. 102-124, mar. 2007.

BourdoukAN, A. Y. "Trajetórias de carreira e arenas políticas". Anais do $5^{\circ}$ Encontro da ABCP. Belo Horizonte, 2006.

Brambor, T.; Ceneviva, R. "Reeleição e continuísmo nos municípios brasileiros". Novos Estudos, São Paulo, n 93, p. 9-21, jul. 2012. 
PARA ONDE IR? A TRAJETÓRIA ELEITORAL DOS PREFEITOS DAS CAPITAIS ESTADUAIS BRASILEIRAS (1996-2014)

BRASIL. Câmara dos Deputados. Conheça os deputados. Disponível em:

<http://www2.camara.leg.br/deputados/pesquisa>. Acesso em: 30 out. 2015.

. TSE (Tribunal Superior Eleitoral). Eleições / Eleições anteriores. Disponível em:

<http://www.tse.jus.br/eleicoes/eleicoes-anteriores/eleicoes-anteriores>. Acesso em: 30 out. 2015.

. TSE (Tribunal Superior Eleitoral). Regras para a candidatura de quem já ocupa cargo político-eletivo. 2015. Disponível em: <http://www.tse.jus.br/institucional/escola-judiciariaeleitoral/revistas-da-eje/artigos/regras-para-a-candidatura-de-quem-ja-ocupa-cargo-politicoeletivo >. Acesso em: 12 jul. 2015.

Figueiredo, A.; Limongi, F. "Congresso Nacional: organização, processo legislativo e produção legal". Cadernos de Pesquisa Cebrap, n 5, out. 1996.

. Liderazgos políticos en la Cámara de Diputados del Brasil. In: HofMEISTER, W. (org.).

Liderazgo político en America Latina: "Dadme un balcón y el país es mio". Rio de Janeiro: Fundação Konrad Adenauer, p. 339-372, 2002.

FleisCHER, D. "Renovação política - Brasil 1978: eleições parlamentares sob a égide do Pacote de Abril". Dados - Revista de Ciência Política, Rio de Janeiro, vol. 23, n², p. 57-82, maio-ago. 1980.

. "O pluripartidarismo no Brasil: dimensões sócio-econômicas e regionais do recrutamento legislativo (1946-1967)". Dados - Revista de Ciência Política, Rio de Janeiro, vol. 24, n 1, p. 49-75, 1981.

FOLHA DE S. PAULO. "Roraima: Justiça cassa Flamarion; adversário assume". 11 nov. 2004. Disponível em: <www1.folha.uol.com.br/fsp/brasil/fc1111200415.htm>. Acesso em: 12 jul. 2015.

FREITAS, R. "Regiões metropolitanas: uma abordagem conceitual". Hum@nae, Recife, vol. 4, n 1, p. 44-53, 2010.

GraçA, L. F. G.; SouzA, C. P. R. "Uso estratégico de eleições alternadas? Efeitos da candidatura para prefeito sobre a votação dos concorrentes ao cargo de deputado federal no Brasil". Opinião Pública, Campinas, vol. 20, n³, p. 326-345, dez. 2014.

IBGE (Instituto Brasileiro de Geografia e Estatística). IBGE Cidades. Disponível em: <http://www.cidades.ibge.gov.br/xtras/perfil.php?lang=\&codmun $=120040$ \&search=acre $\mid$ riobranco>. Acesso em: 12 jul. 2015.

LaVAredA, A.; Telles, H. (orgs.). Como o eleitor escolhe seu prefeito - campanha e voto nas eleições municipais. Rio de Janeiro: Fundação Getúlio Vargas, 2011.

LeOni, E.; Pereira, C.; RenNó, L. "Estratégias para sobreviver politicamente: escolhas de carreiras na Câmara dos Deputados do Brasil". Opinião Pública, Campinas, vol. 9, n 1, p. 44-67, 2003.

MAGALHÃES, L. "Incumbency effects in Brazilian mayoral elections: a regression discontinuity design". Working Paper 12/284. Bristol: CMPO, University of Bristol, feb. 2012. Disponível em:

<http://www.bristol.ac.uk/cmpo/publications/papers/2012/wp284.pdf>. Acesso em: 12 maio 2014.

MAINWARING, S. "Políticos, partidos e sistemas eleitorais: o Brasil numa perspectiva comparativa". Novos Estudos, São Paulo, n² 29, p. 34-58, mar. 1991.

MALUF, R. T. "A carreira política na Câmara Municipal de São Paulo (CMSP)". Tese de Doutorado em Ciência Política. Universidade de São Paulo, São Paulo, 2006.

MANCUSO, W., et al. "Determinantes dos padrões de carreira política dos deputados federais paulistas entre as legislaturas 49a (1991-1995) e 53a (2007-2011)". Opinião Pública, Campinas, vol. 19, n², p. 430-448, nov. 2013. 
MARENCO dos SANTOS, A. "Não se fazem mais oligarquias como antigamente. Recrutamento parlamentar, experiência política e vínculos partidários entre deputados brasileiros (1946-1998)". Tese de Doutorado em Ciência Política. UFRGS, Porto Alegre, 2000.

- "Comparando legislativos: recrutamento parlamentar na Argentina, no Brasil, no Chile e no México". Teoria \& Sociedade, Belo Horizonte, vol. 11, n² 2, p. 42-69, 2004.

MAToS, V. L. C. "O impacto das eleições municipais na representação da Câmara dos Deputados: deputados federais candidatos às eleições para as prefeituras dos municípios". Dissertação de Mestrado em Ciência Política. Iuperj; Cefor/Câmara dos Deputados, Rio de Janeiro, 2010.

MiguEL, L. F. "Capital político e carreira eleitoral: algumas variáveis na eleição para o Congresso brasileiro". Revista Sociologia e Política, Curitiba, n²0, p. 115-134, jun. 2003.

MoreIRA, M. G. R. "Are incumbents advantaged? Evidences from Brazilian municipalities using a quasi-experimental approach". FGV Conferences, $34^{\circ}$ Meeting of the Brazilian Econometric Society, Rio de Janeiro, 2012. Disponível em:

<http://bibliotecadigital.fgv.br/ocs/index.php/sbe/EBE12/paper/view/3778/1519>. Acesso em: 28 mar. 2017.

Nicolau, J. "Como controlar o representante? Considerações sobre as eleições para a Câmara dos Deputados no Brasil". Dados, Rio de Janeiro, vol. 45, n² 2, p. 219-236, 2002.

OliveirA, M. M. F. "A política como profissão. Uma análise de circulação parlamentar na Câmara de Deputados (1946-2007)". Tese de Doutorado em Ciência Política. Universidade de São Paulo, São Paulo, 2009.

Pegurier, F. J. H. "Carreiras políticas e a Câmara dos Deputados brasileira". Tese de Doutorado em Ciência Política. Iuperj, Rio de Janeiro, 2009.

Pereira, C.; Rennó, L. "O que é que o reeleito tem? Dinâmicas político-institucionais locais e nacionais nas eleições de 1998 para a Câmara dos Deputados". Dados, Rio de Janeiro, vol. 44, $\mathrm{n}^{\circ}$ 2, p. $133-172,2001$.

. "O que é que o reeleito tem? O retorno: o esboço de uma teoria da reeleição no Brasil". Revista de Economia Política, São Paulo, vol. 27, n 4, p. 664-683, out.-dez. 2007.

Pinto, S. C. A. "Deputados e prefeitos: o nacional e o local na estrutura de oportunidades políticas no Brasil". Tese de Doutorado em Ciência Política. Universidade do Estado do Rio de Janeiro, Rio de Janeiro, 2012.

Polsby, N. W. "The institutionalization of the U.S. House of Representatives". American Political Science Review, vol. 62, $\mathrm{n}^{\circ} 1$, p. 144-168, mar. 1968.

ROHDE, D. W. "Risk-bearing and progressive ambition: the case of members of the United States House of Representatives". American Journal of Political Science, vol. 23, n 1, p. 1-26, feb. 1979.

SAmuels, D. Ambition, federalism, and legislative politics in Brazil. New York: Cambridge University Press, 2003.

SANTANA, L. "Perfil, trajetórias e ambição política dos legisladores na construção de suas carreiras: Argentina, Brasil, Chile e Uruguai". Teoria \& Sociedade, Belo Horizonte, vol. 16, n 2, p. 130-155, jul.-dez. 2008.

SANTOS, F. Deputados federais e instituições legislativas no Brasil: 1946-1999. In: BosCHI, R.; DINIZ, E.; SANTOS, F. Elites políticas e econômicas no Brasil contemporâneo. São Paulo: Fundação Konrad Adenauer, p. 89-117, 2000. 
PARA ONDE IR? A TRAJETÓRIA ELEITORAL DOS PREFEITOS DAS CAPITAIS ESTADUAIS BRASILEIRAS (1996-2014)

SANTOS, F. Recruitment and retention of legislators in Brazil. In: LoeWenberG, G.; SQUiRE, P.; KIEWIET, R. (orgs.). Legislatures - comparative perspectives on representative assemblies. Ann Arbor: University of Michigan Press, p. 119-145, 2002.

- "Câmara dos Deputados e a estrutura de oportunidades políticas no Brasil: alguns apontamentos acerca das eleições de 2010". Cadernos Aslegis, Brasília, n 40, p. 109-126, maioago. 2010.

SANToS, W. G. "Eleição, representação, política substantiva". Dados, Rio de Janeiro, n 8, p. 7-26, 1971.

. Crise e castigo: partidos e generais na política brasileira. São Paulo: Vértice, 1987.

. "Da poliarquia à oligarquia? Eleições e demanda por renovação parlamentar". Sociedade e Estado, Brasília, vol. 12, nº 1, p. 11-56, jan.-jun. 1997.

. O cálculo do conflito. Belo Horizonte: UFMG, 2003.

SANTOS, W. G. (org.). Votos e partidos. Almanaque de dados eleitorais: Brasil e outros países. Rio de Janeiro: Fundação Getúlio Vargas, 2002.

SCHLesinger, J. A. Ambition and politics: political careers in the United States. Chicago: Randy McNally, 1966.

SCHMITT, R. "Migração partidária e reeleição na Câmara dos Deputados". Novos Estudos, São Paulo, n 54, p. 127-146, jul. 1999.

SILVeIRA, F. E. (org.). Estratégia, mídia e voto: a disputa eleitoral em 2000. Porto Alegre: EdiPUCRS, 2002.

SoARes, G. A. D.; D'ARaújo, M. C. "A imprensa, os mitos e os votos nas eleições de 1990". Revista Brasileira de Estudos Políticos, Belo Horizonte, n 76, p. 163-190, jan. 1993.

VALOR ECONÔMICO. "STF proíbe candidaturas de prefeitos itinerantes". 1 ago. 2012. Disponível em: <http://www.valor.com.br/politica/2773260/stf-proibe-candidatura-de-prefeitos-itinerantes>. Acesso em: 12 jul. 2015.

\section{Não citadas, mas consultadas para classificar as situações particulares}

AQUi AMAPÁ. "Adeus comandante Annibal Machado". s.d. Disponível em:

<http://www.aquiamapa.com.br/site/index.php?option=com_content\&view=article\&id=200: adeuscomandante-annibal-barcellos\&catid=46: cidade\&Itemid=67>. Acesso em: 12 jul. 2015.

BLOGUe RobSON PIRES. "Micarla de Sousa sofre um acidente vascular cerebral". 26 fev. 2014. Disponível em: < http://www.robsonpiresxerife.com/notas/micarla-de-sousa-sofre-um-acidentevascular-cerebral/>. Acesso em: 28 mar. 2017.

CAvalcante, G. "Na hora da onça beber água". Jornal Opção, n² 2.045, 14-20 set. 2014. Disponível em: <http://www.jornalopcao.com.br/tocantins/na-hora-da-onca-beber-agua-15095/>. Acesso em: 12 jul. 2015.

Cleber Toledo. "Confira quem já ocupou o cargo de prefeito de Palmas em outras gestões". 6 out. 2012. Disponível em: <www.clebertoledo.com.br/eleicoes/2012/10/06/48836-confira-quem-jaocupou-o-cargo-de-prefeito-de-palmas-em-outras-gestoes>. Acesso em: 12 jul. 2015. 
CRÍTICA, A. "Amazonino Mendes passa por cirurgia no coração em São Paulo". 22 ago. 2012. Disponível em: <http://www.acritica.com/channels/manaus/news/amazonino-mendes-passa-porcirurgia-no-coracao-em-sao-paulo>. Acesso em: 12 jul. 2015.

DANTAS, I. Eleições em Sergipe - 1985-2000. Rio de Janeiro: Tempo Brasileiro, 2002.

DIÁRIO DA MANHÃ. "Nion Albernaz: 'PSDB entra para ganhar em Goiânia'". 15 jul. 2015. Disponível em: <http://www.dm.com.br/politica/2015/07/nion-albernaz-psdb-entra-para-ganhar-emgoiania.html>. Acesso em: 19 out. 2015.

Dí́RIO Do GRANDE ABC. "Prefeito do Rio Branco quer vaga na Câmara Federal". 13 set. 2000. Disponível em: <http://www.dgabc.com.br/Noticia/447873/prefeito-do-rio-branco-quer-vaga-nacamara-federal?referencia=buscas-lista>. Acesso em: 12 jul. 2015.

FATO REAL. "Reforço na oposição... Ex-prefeito de Boa Vista assina filiação ao PTB". 6 set. 2013. Disponível: <http://www.fatoreal.blog.br/politica/reforco-oposicao-ex-prefeito-boa-vista-assinafiliacao-ptb/>. Acesso em: 12 jul. 2015.

. "Iradilson é nomeado Ouvidor-Geral do estado... como assim, produção"?. 28 maio 2014. Disponivel em: <http://www.fatoreal.blog.br/politica/iradilson-e-nomeado-ouvidor-geral-estadocomo-assim-producao/>. Acesso em: 12 jul. 2015.

FOCANDO a NOTícIA. "Agra apoia Cartaxo 'com tranquilidade' e diz 'quero recompor o campo da esquerda'". 26 jun. 2012. Disponível em: <http://www.focandoanoticia.com.br/agra-apoia-cartaxocom-tranquilidade-e-diz-quero-recompor-o-campo-da-esquerda/>. Acesso em: 31 jul. 2015.

FolHA DE S. PAULO. "Problema de saúde faz prefeito de Porto Velho renunciar ao cargo". 3 dez. 1998. Disponível em: <www1.folha.uol.com.br/fsp/cotidian/ff03129825.htm>. Acesso em: 12 jul. 2015.

"Sem opções, Pitta ingressa no PTN". 9 set. 1999. Disponível em:

<http://www1.folha.uol.com.br/fsp/cotidian/ff09099926.htm>. Acesso: 28 mar. 2017.

"Genro atribui escolha à aproximação de facções". 11 abr. 2000. Disponível em: <http://www1.folha.uol.com.br/fsp/brasil/fc1104200023.htm>. Acesso em: 12 jul. 2015.

. "73\% reprovam governo Pitta e 60 querem seu impeachment". 20 jul. 2000. Disponível em: <www1.folha.uol.com.br/fsp/cotidian/ff09049901.htm>. Acesso em: 12 jul. 2015.

"Novo prefeito rompe acordo com ministro e demite secretários". 16 mar. 2004. Disponível em: <http://www1.folha.uol.com.br/folha/brasil/ult96u59219.shtml>. Acesso em: 12 jul. 2015.

. "Amazonino Mendes desiste de disputar reeleição em Manaus". 1 jul. 2012. Disponível em: <http://www1.folha.uol.com.br/poder/2012/07/1113438-amazonino-mendes-desiste-dedisputar-reeleicao-em-manaus.shtml>. Acesso em: 12 jul. 2015.

G1. "Gestão de Micarla em Natal é ruim ou péssima para 93\%, aponta Ibope". 31 out. 2012a. Disponível em: <http://g1.globo.com/rn/rio-grande-do-norte/noticia/2012/10/gestao-de-micarlaem-natal-e-ruim-ou-pessima-para-93-aponta-ibope.html>. Acesso em: 12 jul. 2015.

. "Micarla de Sousa é afastada da prefeitura de Natal pela justiça". 31 out. 2012b. Disponível em: <http://g1.globo.com/rn/rio-grande-do-norte/noticia/2012/10/micarla-de-sousa-eafastada-da-prefeitura-de-natal-pela-justica.html>. Acesso em: 12 jul. 2015.

. "Vereadores rejeitam contas e deixam João Henrique inelegível por 8 anos". 13 dez. 2012. Disponível em: <http://g1.globo.com/bahia/noticia/2012/12/vereadores-rejeitam-contas-e-deixamjoao-henrique-inelegivel-por-8-anos.html>. Acesso em: 12 jul. 2015. 
PARA ONDE IR? A TRAJETÓRIA ELEITORAL DOS PREFEITOS DAS CAPITAIS ESTADUAIS BRASILEIRAS (1996-2014)

G1. "Duciomar Costa tem recurso indeferido no TSE e segue impugnado". 4 out. 2014. Disponível em: <http://g1.globo.com/pa/para/eleicoes/2014/noticia/2014/10/duciomar-costa-tem-recursoindeferido-no-tse-e-segue-impugnado.html>. Acesso em: 30 out. 2015.

Gazeta Central. "Ex-prefeito Chiquilito é homenageado com nome em parte da BR-364". 22 jul. 2011. Disponível em:

<http://www.gazetacentral.com.br/MateriasDetalhes.php?Codigo=452\&Titulo=Ex_prefeito_Chiquilit o_e_homenageado_com_nome_em_parte_da_BR_364>. Acesso em: 12 jul. 2015.

Gazeta Digital. "Ex-prefeito Celio de Castro sepultado em BH". 22 jul. 2008. Disponível em: <http://www.gazetadigital.com.br/conteudo/show/secao/10/materia/183325>. Acesso em: 12 jul. 2015.

GAZETA DO POVO. "José Maranhão toma posse na Paraíba sob ameaça de cassação". 19 fev. 2009. Disponível em: <http://www.gazetadopovo.com.br/vida-publica/jose-maranhao-toma-posse-naparaiba-sob-ameaca-de-cassacao-bfnquvboim8vgks4vtmnkgvgu>. Acesso em: 30 out. 2015.

JM NotíCIA. "Deputada descarta candidatura de Raul Filho nestas eleições; Raul pensa na capital para 2016". 18 jun. 2014. Disponível em: <http://www.jmnoticia.com.br/politica-3531-deputadadescarta-candidatura-de-raul-filho-nestas-eleicoes-raul-pensa-na-capital-para2016.htmI\#.VFVsjPnF_cY>. Acesso em: 12 jul. 2015.

JORNAL DO COMÉRCIO. "João Verle analisa volta do déficit nas finanças de Porto Alegre". Disponível em: <http://jcrs.uol.com.br/site/noticia.php?codn=135681>. Acesso em: 31 jul. 2015.

NE NotíCIAS. "Déda é o único favorito do PT em todo o país". 29 jun. 2006. Disponível em: <http://www.nenoticias.com.br/50815_deda-e-o-unico-favorito-do-pt-em-todo-o-pais.html>. Acesso em: 30 out. 2015.

PATURY, F. "O eleitor do Amazonas rejeita Amazonino". Época, 28 jul. 2014. Disponível em: $<$ http://epoca.globo.com/colunas-e-blogs/felipe-patury/noticia/2014/07/o-eleitor-do-bamazonasrejeita-amazoninob.html>. Acesso em: 12 jul. 2015.

Portal PRUdentino. "Galindo figura em cadastro de condenados por improbidade". 30 jan. 2012. Disponível em:

<http://www.portalprudentino.com.br/noticia/noticias.php?id=26772\&titulo=galindo-figura-emcadastro-de-condenados-por-improbidade>. Acesso em: 31 jul. 2015.

POtIGUaR Notícias." Micarla encerra carreira que já tinha sido encerrada". 30 abr. 2013. Disponível em: <http://www.potiguarnoticias.com.br/noticias/23351/micarla-encerra-carreira-que-ja-tinhasido-encerrada>. Acesso em: 12 jul. 2015.

RD NEWS. BLOG DO ROMILSON. "Em encontro, petebista já lança Norma Galindo à prefeitura ou vice". 22 maio 2012. Disponível em: <http://www.rdnews.com.br/blog-do-romilson/conteudo/emencontro-petebista-ja-lanca-norma-galindo-a-prefeita-ou-vice/34783>. Acesso em: 31 jul. 2015.

Silva, I. L. S. M. "A pesquisa de opinião pública como ferramenta de marketing político: um estudo de caso em Aracaju". Dissertação de Mestrado em Administração. Universidade Federal da Paraíba, João Pessoa, 2001.

Silva, N. E. "Um governo na floresta". Tese de Doutorado em Ciências Sociais. Pontifícia Universidade Católica de São Paulo, São Paulo, 2009.

TARDE, A. "João Henrique tenta manter poder por meio de mulher e filho". 9 jul. 2014. Disponível em: <http://atarde.uol.com.br/politica/eleicoes/noticias/joao-henrique-tenta-manter-poder-pormeio-de-mulher-e-filho-1604614>. Acesso em: 12 jul. 2015. 
TERRA. "SP: Mercadante vence prévia e será candidato do PT". 8 maio 2006. Disponível em: <http://noticias.terra.com.br/eleicoes2006/interna/0,,OI995104-EI6653,00.html>. Acesso em: 12 jul. 2015.

TERRA. "Mozarildo surpreende e consegue reeleição em RR". 2 out. 2006. Disponível em: <http://noticias.terra.com.br/eleicoes2006/interna/0,,OI1169071-EI6680,00Mozarildo+surpreende+e+consegue+reeleicao+em+RR.html>. Acesso em: 30 out. 2015.

. "Datafolha: Fogaça e Tarso empatam na disputa no RS". 4 abr. 2010. Disponível em: <http://noticias.terra.com.br/brasil/noticias/0,,OI4359550-EI7896,00Datafolha+Fogaca+e+Tarso+empatam+na+disputa+no+RS.html>. Acesso em: 30 out. 2015.

"PT barra atual prefeito e lança senador como candidato em Recife". 5 jun. 2012.

Disponível em: <https://noticias.terra.com.br/brasil/politica/pt-barra-atual-prefeito-e-lancasenador-como-candidato-em-recife,867c0a43aa1da310VgnCLD200000bbcceb0aRCRD.html>. Acesso em: 12 jul. 2015.

TRIgUeiro, D. "Fim de papo: Agra rompe com Ricardo, descarta Estela e avisa que vai participar da campanha de outro palanque". Jun. 2012. Disponível em:

<http://dayanapb.blogspot.com.br/2012/06/fim-de-papo-agra-rompe-com-ricardo.html>. Acesso em: 31 jul. 2015.

ÚlTIMO SEGUNDO. "Marta Suplicy". s.d. Disponível em: <http://ultimosegundo.ig.com.br/martasuplicy/4f7dfc36a0769351110000f0.html>. Acesso em: 12 jul. 2015.

Zero Hora. "Morre, aos 75 anos, o ex-prefeito de Porto Alegre João Verle". 7 nov. 2015. Disponível em: <http://zh.clicrbs.com.br/rs/porto-alegre/noticia/2015/11/morre-aos-75-anos-o-ex-prefeitode-porto-alegre-joao-verle-4897179.html>. Acesso em: 7 nov. 2015.

\section{Resumo}

Para onde ir? A trajetória eleitoral dos prefeitos das capitais estaduais brasileiras (1996-2014)

Este artigo analisa a trajetória dos prefeitos das 26 capitais estaduais brasileiras eleitos no período 1996-2008 após chegarem ao cargo. Busca identificar se procuraram novos postos eletivos e, em caso positivo, quais foram eles e os resultados alcançados, de modo a verificar a presença de algum padrão predominante nessas decisões com vistas a dar continuidade à carreira. $O$ universo da pesquisa é formado por 77 indivíduos, quatro disputas de âmbito municipal (2000, 2004, 2008 e 2012) e outras cinco de âmbitos estadual e nacional (1998, 2002, 2006, 2010 e 2014), tendo o TSE como fonte principal. $\mathrm{O}$ fato de tais atores ocuparem o cargo de chefe do Executivo de um município com grande visibilidade e importância política e econômica no seu respectivo estado foi o ponto de partida do artigo, pois tais condições abrem a perspectiva de que possam alcançar outros postos eletivos relevantes na hierarquia política. Ao considerar as situações específicas desses prefeitos (reeleitos, desistentes da reeleição, derrotados e renunciantes em meio ao mandato), os resultados apontam que a ampla maioria pretende continuar na carreira política, inicialmente ao renovar o mandato e, na sequência, buscar outro posto eletivo, com preferência aos cargos legislativos. A taxa de sucesso na busca da reeleição é elevada, mas, ao ambicionar um cargo distinto, preponderam as derrotas, sendo que o posto mais seguro a ser alcançado é o de deputado federal.

Palavras-chave: carreira política; prefeito; ambição política; capitais estaduais; eleições 


\begin{abstract}
Where to go? The electoral trajectory of the mayors of Brazilian state capitals (1996-2014)

The present work analyzes the trajectories of the mayors of the 26 Brazilian state capitals between 1996 and 2008 after entering office. It seeks to identify whether or not they sought new elected positions-if so, what were the positions specifically and what were the results of their endeavors-in order to verify the presence of a predominant pattern in such decisions. The research universe consists of 77 individuals, four municipal disputes (2000, 2004, 2008, and 2012), and five others at the state and national levels (1998, 2002, 2006, 2010, and 2014). The main source of data is the TSE. The fact that these actors occupy the chief executive post of a municipality with high visibility and political and economic importance in their respective states was the starting point of the work, because these conditions provide the prospect that they may reach other relevant elective positions in the political hierarchy. When considering the specific situations of these mayors (re-elected, resigned to re-election, defeated, and resigned in office), the results indicate that the vast majority intends to continue in the political career, initially by renewing their terms and, subsequently, by seeking another office, with preference to the legislatures. The success rate in the search for reelection is high; however, when it comes to ambitions for a different position, defeats prevailed, and the safest position to be reached is that of federal deputy.
\end{abstract}

Keywords: political career; mayor; political ambition; state capitals; elections

\title{
Resumen
}

¿Para dónde ir? La trayectoria electoral de los alcaldes de las capitales de los estados brasileños (1996-2014)

Se analiza la trayectoria de los alcaldes de las 26 capitales de los estados brasileños elegidos en el período de 1996 a 2008 después de llegar al cargo. Busca identificar si buscaron nuevos puestos electorales, y si es así, quiénes fueron y cuáles fueron los resultados obtenidos, con el objetivo de verificar la presencia de una norma predominante en este tipo de decisiones con el fin de continuar la carrera. El universo de la investigación se compone de 77 individuos, cuatro disputas municipales $(2000,2004,2008$ y 2012) y cinco a nivel estatal y nacional (1998, 2002, 2006, 2010 y 2014$)$ y teniendo el TSE como la principal fuente. El hecho de que estos agentes ocupen el cargo de jefe del ejecutivo de un municipio con alta visibilidad e importancia política y económica en su estado respectivo fue el punto de partida del artículo, ya que los resultados abren la posibilidad de que puedan llegar a otros cargos electorales importantes en la jerarquía política. Al considerar las circunstancias específicas de estos alcaldes (reelegidos, abandonos de la reelección, derrotados y renunciantes en medio del mandato), los resultados indican que la gran mayoría tiene la intención de continuar con la carrera política, en un principio para renovar el mandato y, como consecuencia, buscar otro cargo electivo con preferencia a cargos en el legislativo. La tasa de éxito en la búsqueda de la reelección es alta, pero al ambicionar una posición distinta predominan las derrotas, y la posición más segura para ser alcanzada es la de diputado federal.

Palabras clave: trayectoria política; alcalde; ambición política; capitales estaduales; elecciones

\section{Résumé}

Vers où aller? La trajectoire électorale des maires des capitales d'états brésiliens (1996-2014)

On analise la trajectoire des maires des 26 capitales d'états brésiliens élus pendant la période 1996-2008, une fois qu'ils ont pris leurs fonctions. On identifie s'ils ont cherché de nouvelles fonctions électives et, si c'est le cas, lesquelles et quels sont les résultats obtenus de manière à vérifier l'existence $d$ 'un modèle prédominant dans les décisions de poursuivre leur carrière politique. L'univers de cette recherche est composé de 77 personnes, quatre disputes au niveau municipal (2000, 2004, 2008 et 2012) et cinq autres aux niveaux départemental et national (1998, 2002, 2006, 2010 et 2014) dont le TSE (Tribunal Supérieur Électoral) est la source principale. Le fait 
que ces acteurs occupent le poste de chef du pouvoir exécutif d'une municipalité ayant une grande visibilité et de I' importance politique et économique dans leur département a été le point de départ de cet article, parce que ces conditions permettent qu 'ils puissent atteindre d'autres postes électifs plus importants dans la hiérarchie politique. En tenant compte des circonstances particulières de ces maires (les réélus, les vaincus, ceux qui ont décroché ou renoncé à mi-mandat) les résultats indiquent que la majorité a l'intention de poursuivre sa carrière politique, d'abord en renouvelant leur mandat, puis en cherchant un autre poste électif, de préférence au pouvoir législatif. Le taux de réussite dans la recherche d'une réélection est élevé, mais convoiter une position distincte se solde souvent par une défaite, la position ayant le plus de chances d'être obtenue étant celle de député fédéral.

Mots-clés: carrière politique; maire; ambition politique; capitales d'états; élections

Artigo submetido à publicação em 12 de julho de 2015.

Versão final aprovada em 10 de março de 2017. 